\title{
Improving Tumor Retention of Effector Cells in Adoptive Cell Transfer Therapies by Magnetic Targeting
}

\author{
Laura Sanz-Ortega ${ }^{1}\left(\mathbb{D}\right.$, José Manuel Rojas ${ }^{2}\left(\mathbb{D}\right.$ and Domingo F. Barber ${ }^{3, *}$ (i) \\ 1 Center for Hematology and Regenerative Medicine (HERM), Department of Medicine, Karolinska Institute, \\ 14183 Stockholm, Sweden; laura.sanz@ki.se \\ 2 Animal Health Research Centre (CISA)-INIA, Instituto Nacional de Investigación y Tecnología Agraria y \\ Alimentaria, 28130 Madrid, Spain; rojas.jose@inia.es \\ 3 Department of Immunology and Oncology, and NanoBiomedicine Initiative, Centro Nacional de \\ Biotecnología (CNB)-CSIC, 28049 Madrid, Spain \\ * Correspondence: dfbarber@cnb.csic.es
}

Received: 23 July 2020; Accepted: 24 August 2020; Published: 27 August 2020

check for updates

\begin{abstract}
Adoptive cell transfer therapy is a promising anti-tumor immunotherapy in which effector immune cells are transferred to patients to treat tumors. However, one of its main limitations is the inefficient trafficking of inoculated effector cells to the tumor site and the small percentage of effector cells that remain activated when reaching the tumor. Multiple strategies have been attempted to improve the entry of effector cells into the tumor environment, often based on tumor types. It would be, however, interesting to develop a more general approach, to improve and facilitate the migration of specific activated effector lymphoid cells to any tumor type. We and others have recently demonstrated the potential for adoptive cell transfer therapy of the combined use of magnetic nanoparticle-loaded lymphoid effector cells together with the application of an external magnetic field to promote the accumulation and retention of lymphoid cells in specific body locations. The aim of this review is to summarize and highlight the recent findings in the field of magnetic accumulation and retention of effector cells in tumors after adoptive transfer, and to discuss the possibility of using this approach for tumor targeting with chimeric antigen receptor (CAR) T-cells.
\end{abstract}

Keywords: magnetic targeting; cancer immunotherapy; adoptive cell transfer therapy; chimeric antigen receptor (CAR) T-cells

\section{Introduction}

For many years, conventional treatments such as surgery, chemotherapy and radiotherapy have been the main options to treat cancer. However, the high relapse rates together with the numerous side effects that these therapies produce highlight the need for developing new supplementary treatments to overcome these limitations and problems. In recent years, cancer immunotherapy, which seeks to fight cancer by enhancing the immune response, has re-emerged as one of the most promising therapies to solve these issues [1]. One of the physiological functions of the immune system is to recognize and eliminate altered cells due to tumor transformation. The emergence of a tumor nonetheless implies that the immune response failed to be adequately triggered and this could be due to several non-excluding causes such as (i) the inability to detect tumor-associated antigens (TAAs), (ii) the recognition of tumor antigens as one's self, creating a regulatory response rather than an effector one, (iii) a reduced infiltration of the effector cells in the tumor, and iv) the presence of immunomodulatory factors that generate an immunosuppressive tumor environment [2]. Antitumor immunotherapy seeks to enhance the response of components of the immune system so that they can overcome the tumor escape mechanisms and establish an effective antitumor response [3,4]. Broadly speaking, cancer immunotherapy strategies 
can be classified as active or passive [5,6]. Active immunotherapy aims at stimulating the immune system to attack tumor cells through vaccination, non-specific immunomodulation or through the activation of antigen-specific receptors, while passive immunotherapy consists of the administration of agents such as monoclonal antibodies or lymphocytes that would increase the existing antitumor response [7]. This review will focus on adoptive cell therapy (ACT) and how magnetic targeting can improve this passive strategy.

\section{Adoptive Cell Therapy (ACT) and Its Limitations}

ACT involves the isolation of immune cells from a patient or donor, which can be modified and expanded ex vivo under optimal conditions to then be reinfused back to the patient [8-10]. This approach is based on the premise that a large population of cells with antitumor activity will migrate to the tumor and mediate its destruction. The first clinical trials using ACT were pioneered by Rosenberg et al., who used lymphokine-activated killer cells (LAK cells), which consisted of interleukin (IL)-2 activated autologous peripheral blood mononuclear cells, along with high doses of IL-2, for the treatment of tumors such as melanoma or colorectal cancer [11]. The clinical benefits in these studies were limited, however, since the high doses of systemic IL-2 induced some severe toxicity [12]. Since then, different cell types, mainly based on T or natural killer (NK) cells, have been investigated for use in ACT.

Although ACT has achieved high regression rates in some types of cancer, there is still a lack of response in other cases [13]. This can be due to numerous factors that affect the transferred cells including their proliferation potential [14,15], their persistence [16], their differentiation state and phenotype [17,18], as well as their ability to migrate and infiltrate the tumor [19-21]. Another important limiting factor for ACT success is often related to the failure to isolate and expand in sufficient numbers tumor-specific $\mathrm{T}$ cells that mediate tumor destruction $[9,22]$. Both the time and the cost required to produce these cells are a great challenge [23]. Tumor cell immunogenicity also plays a crucial role in cancer immunotherapy. Response rates to immunotherapeutic approaches (such as programmed-death ligand receptor 1 (PD-1) pathway blockade) increase in tumors with high mutational rates [24,25], indicating that tumor cells carrying a greater amount of mutations are more readily detectable and thus targetable by immunotherapy. Consequently, ACT is more likely to be effective in tumors with high mutation burdens.

It is well known that the trafficking of an adequate number of effector cells to the tumor region is a critical step in the development of an antitumor immune response. This process is dynamic and highly regulated, and the optimal antitumor responses in several cancers positively correlate with an increase in the infiltration of antitumor effector cells [26-29]. However, it often appears in ACT that, both in humans $[30,31]$ and in mice [32,33], only a small percentage of the transferred cells manage to migrate to the tumor and infiltrate it. These cells also travel indiscriminately to multiple organs [34], and this could have pathological consequences. Therefore, one of the biggest challenges in ACT is to overcome the barriers that restrict the access of effector cells to the tumor niche and design new strategies to increase the traffic of these cells to the tumor microenvironment.

Antitumor effector cells are recruited from the circulation to the tumor site by a sequential process involving endothelial adhesion, rolling, chemotaxis and finally, extravasation $[35,36]$. The reasons for the low trafficking of effector cells to the tumor are still a topic of active research. It is known that multiple mechanisms can prevent the infiltration of effector cells in tumors such as: (i) the mismatch between the chemokine receptors and the chemokine pool in the tumor environment [37-40], (ii) the decrease in the expression of adhesion molecules, (iii) the aberrant tumor vasculature that can promote irregular blood flow and therefore inefficient traffic of immune cells [41], and (iv) the possible role of the tumor endothelium as a barrier [42]. In summary, tumors are able to create multiple cellular and molecular barriers that restrict the efficient entry of effector cells within the intratumoral regions (Figure 1). 


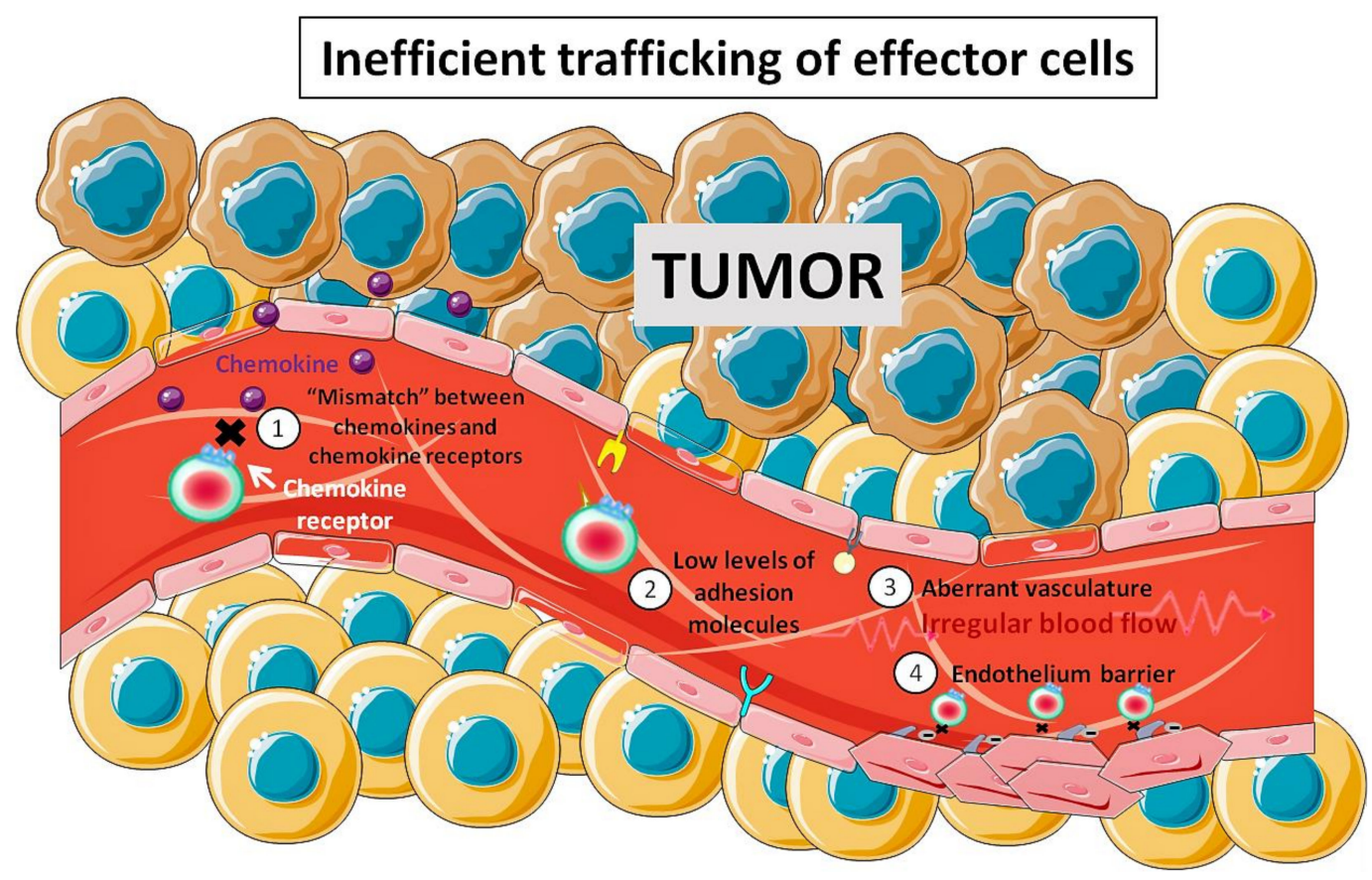

Figure 1. Main barriers that restrict the efficient traffic of effector cells towards tumors. The tumor microenvironment is a hostile environment for antitumor effector cell infiltration. This is achieved through multiple mechanisms such as: (1) mismatch between the chemokine receptors and chemokine pool in the tumor microenvironment; (2) decrease in the expression of adhesion molecule on the tumor endothelium; (3) aberrant vasculature that leads to inefficient traffic of immune cells; (4) tumor endothelium acting as a barrier.

The mismatch between the chemokine receptors expressed by the effector cells and the chemokines secreted by tumors can be responsible for suboptimal traffic of immune cells in the tumor [35]. Numerous chemokines have been described to regulate the migration of $\mathrm{T}$ and $\mathrm{NK}$ cells towards the tumor. C-X-C Motif Chemokine Receptor 3 (CXCR3) is one of the main receptors that is activated in tumor infiltrating lymphocytes (TILs) in melanoma [38], colorectal cancer [40] and breast cancer [37]. Efficient traffic of cytotoxic T lymphocytes (CTLs) to metastatic sites in melanoma patients correlates with the expression of C-X-C Motif Chemokine Ligand 9 (CXCL9) and CXCL10 which are CXCR3 ligands. This chemokine receptor has been found deregulated in effector T cells [38]. Additionally, not all tumors express enough CXCR3 ligands $[37,38]$, which may result in inefficient recruitment of effector and memory CD8 ${ }^{+}$ $\mathrm{T}$ cells. CXCR6 is another important chemokine receptor overexpressed in activated $\mathrm{T}$ cells. Its absence caused a decrease in T cell infiltration in breast tumors, which prevented tumor regression in a breast cancer model [39]. One option to overcome ineffective homing is to genetically modify the transferred cells to improve their ability to effectively migrate to the tumor. Kershaw et al. demonstrated that the introduction of the CXCR2 chemokine receptor in $\mathrm{T}$ cells allowed for their effective migration to tumor cells in vitro [43]. Since then, multiple studies aiming at increasing the traffic of $\mathrm{T}$ and NK cells to the tumor through modifications of other chemokine receptors have been published. Di Stasi et al. showed that C-C Motif Chemokine Receptor 4 (CCR4) expression in CD30-directed chimeric antigen receptor (CAR) T cells improved migration towards CD30 $0^{+}$Hodgkin lymphoma, which secreted the CCR4 ligand CCL17 (C-C Motif Chemokine Ligand 17). In addition, CCR4 ${ }^{+}$CD30-directed CAR-T cell transfer resulted in superior antitumor activity in a xenotransplant model due to increased infiltration of $\mathrm{T}$ cells in the tumor [44].

Another obstacle for $\mathrm{T}$ and NK cell tumor infiltration is the presence of an aberrant vasculature in the tumor, which can promote an irregular blood flow leading to inefficient cell trafficking in the tumor microenvironment [41]. In addition, tumor endothelium has been described as a barrier that prevents 
infiltration of CTLs [42]. To overcome these issues, several strategies such as the use of antibodies against vascular endothelium growth factor (VEGF) and its receptors [41,45,46], irradiation [47], or cytokine targeting (e.g., tumor necrosis factor- $\alpha(\mathrm{TNF} \alpha)$ ) with tumor vasculature NGR (Asn-Gly-Arg) and RGR (Arg-Gly-Arg) homing peptides [41,48], have focused on the normalization of blood vessels in the tumor to facilitate immune cell infiltration. All of these strategies have been shown to increase tumor infiltration. CAR technology has also been used to target endothelial cell components such as the $\alpha V / \beta 3$ integrin [49] or the VEGF-2 receptor overexpressed in the tumor vasculature [50] to remove the aberrant vasculature and increase the traffic of effector cells towards the tumor, which in turn could mediate tumor regression.

The efficient traffic of $\mathrm{T}$ and NK cells to the tumor environment is critical for developing successful antitumor immunotherapy. Although new strategies that increase antitumor immune cell traffic to the tumor are being investigated, they often rely on specific mechanisms that differ between tumor types. The design of more general approaches, which can be applied to a wide variety of tumors, would be of great interest.

\section{Nanobiomedicine}

Nanotechnology is a multidisciplinary area based on the design and use of materials and systems on the nanometric scale. Biomedicine is one of the areas in which nanotechnology has had a major impact, giving rise to nanobiomedicine. Nanobiomedicine uses nanotechnological systems such as nanoparticles, nanocells, nanoemulsions, etc., for different biomedical applications such as prediction, prevention, early diagnosis and personalized therapy, among others [51]. Nanotechnological solutions can present several advantages over conventional delivery routes: treatments can be controlled and directed more specifically, stability can be prolonged, and degradation delayed. This in turn implies that higher concentrations of the active ingredient in the desired place can be achieved, thus increasing the effectiveness of the treatment and decreasing systemic toxicity.

\subsection{Nanoparticles as the Base of Localized Delivery System}

As previously mentioned, a main limitation in most treatments that use drugs or biomolecules is their low in vivo efficacy. As a result, high concentrations of bioactive agents are used to obtain the desired effect, thus causing multiple adverse effects due to off-target interactions, which can sometimes lead to high toxicity. ACT has the advantage over conventional therapies of presenting low systemic toxicity as it employs tumor specific effector cells. ACT application is, however, limited by two main issues: (i) the difficulty to obtain and expand a high enough number of specific effector cells, and (ii) the dissemination of transferred cells throughout the body. Nanotechnology could represent a two-fold solution to solve these types of problems by reducing the need for cell expansion and by concentrating the effects of ACT. Nanoparticles (NPs) are one of the most commonly used nanosystems in biomedicine to improve therapeutic efficacy. NP-based systems have been mainly used to specifically release drugs or biomolecules. They present two main advantages: (i) their small size allows them to reach certain areas inaccessible to other delivery systems and (ii) they can be directed towards a desired area by active or passive strategies, thus reducing the amount of bioactive agent necessary to achieve therapeutic effects in a given location and consequently minimizing the dose and the systemic toxicity.

These characteristics of nanotechnological solutions are critical when attempting to improve the action of a drug in a specific area, as occurring in cancer or in organ-specific autoimmune disease. Conventional therapies tend to disperse throughout the body with only part of the bioactive agent reaching the site of action. NPs can be directed to the site of action through active or passive strategies [52]. Passive targeting strategies rely on the NP size which usually accumulates passively in inflamed regions or tumor masses due to an increase in permeability in those areas, a phenomenon known as enhanced permeability and retention (EPR) effect [53]. The therapeutic potential of this effect has been illustrated in several preclinical and clinical trials that demonstrated that the binding of antitumor drugs to NPs could increase their effectiveness compared to the administration of the drug 
alone [54]. Active targeting strategies seek to actively direct the NPs towards the region of interest. Several strategies have been developed for active targeting such as associating the NPs to specific ligands that direct them to a specific tissue type [55]. Another very promising strategy is the use of magnetic NPs (MNPs) that can be precisely located in the desired area by using an external magnetic field (EMF) [56].

\subsection{Magnetic Nanoparticles}

The idea of MNPs as transport agents that could be targeted and concentrated in a specific region by using an EMF was first proposed by Freeman et al. in $1960[52,57,58]$, and it is based on the competition between the forces exerted on the MNPs by the blood flow and the EMF applied. When the latter predominates, the MNPs can be retained in the desired area. To be used in biomedicine, it is important that MNPs present several properties that make them biocompatible and prevent their toxicity. In addition, their design properties should be tailored to their final application [57]. In the case of MNPs, these characteristics are defined by the magnetic material of the core as well as by their coating. MNP can be categorized depending on the metallic core (e.g., iron, cobalt, nickel, etc.) and the coating employed for their biological application.

The magnetic material must provide essential inherent characteristics, such as the superparamagnetic behavior, to fit the NP's intended use. In superparamagnetic materials, fluctuations in the direction of magnetization affect the entire particle, as these have a single magnetic domain due to their small size, which makes their magnetic behavior reversible when applying a magnetic field. In larger particles, for instance for iron metallic cores $>20 \mathrm{~nm}$, the magnetic behavior is not reversible. In biomedicine, the concept of superparamagnetism is especially relevant, since in the absence of an EMF, the material does not have a residual magnetization, thus avoiding the attraction and agglomeration between particles, which could cause problems such as embolization in the bloodstream. Another important consideration is that the magnetic core needs to be biodegradable or easily excreted. NPs with iron cores can be processed by cells by using the biochemical pathways of iron metabolism [59-61]. Finally, the magnetic core must provide high magnetization, so that the movement of the NPs can be controlled with an EMF and can be immobilized in the desired region. The present review will focus on iron oxide NPs, as these have been most actively researched due to their biocompatibility.

MNP coating will provide NPs with additional characteristics tailored for their use [62]. Coating MNPs with biocompatible compounds prevents their possible toxicity, reduces their immunogenicity and increases their residence time in blood. Besides, the coating can provide the MNPs with the ability to bind certain compounds when a targeting moiety is used. Furthermore, when the MNP coating presents a surface charge at physiological $\mathrm{pH}$, it allows stabilization and prevents aggregation due to the repulsion forces between charges of the same sign.

MNP coating can be achieved through adsorptive or covalent linking to the metallic core (reviewed in [63]). A wide range of polymer formulations has been described to confer stabilizing properties to the MNPs in biological fluids and can allow grafting of supplemental functionalizing biological molecules if required [64]. This endows MNPs with great versatility since they can be chemically manipulated to become vehicles capable of transporting magnetically their cargo to the site of interest.

\subsection{MNP for $A C T$}

As previously mentioned, ACT is a very promising therapeutic approach for cancer treatment. NP-based strategies have been used to modify T cell activity to promote antitumor activity $[65,66]$. NP-modified T cells have even been employed as a chemotherapy carrier for disseminated tumors [67]. Although these strategies proved effective, they can be technically challenging. They also do not address one of the main limitations of ACT, i.e., the reduced migration and the inefficient infiltration of effector $\mathrm{T}$ and NK cells in the tumor microenvironment. Therefore, there is a clear need for strategies that allow one to increase the traffic of the transferred cells to the tumor, thus allowing an 
effective antitumor action and complete tumor eradication [68]. MNP application in biomedicine can improve the effectiveness of a treatment and decrease its toxicity, so combining MNP use with ACT is a very attractive idea. Attaching MNPs to effector lymphoid cells used for ACT to guide them to the tumor site with the application of an EMF is therefore a promising concept. Moreover, increasing the EMF application time or repeating EMF application could also improve the magnetic targeting [56]. Several studies using this type of strategy have been carried out, but mainly with the objective of accumulating stem cells, macrophage or mesenchymal cells as well as dendritic cells (DCs) in regenerative therapies and autoimmune disorders [69-74]. Its use with lymphoid cells, such as $\mathrm{T}$ or NK cells for cancer or autoimmunity treatments, has been very limited [75].

Unlike DCs and macrophages, effector cells such as T and NK cells are characterized by their high motility and for being continuously in circulation. The magnetic targeting of these effector cells could improve their migration to the tumor and promote their accumulation and infiltration in it. This strategy, if implemented correctly, could solve one of the main problems of ACT.

The application of an EMF could lead to an increase in the adhesion time of these cells in the region of interest and, therefore, in their infiltration within the tumor. Only a few studies have addressed the influence of MNPs on the migration and functionality of immune system cells [76]. As promising as this strategy appears, it would only serve as long as the key functional aspects of effector cells are not affected by the presence of MNPs and the application of an EMF.

We and others have recently demonstrated the feasibility of this approach and analyzed the effects of the combined use of magnetic nanoparticles and the application of an external magnetic field, to promote the accumulation and retention of lymphoid cells [77-81]. The following sections of this review will highlight some of the recent findings on the effects of MNPs on lymphoid cells, their specific targeting through the application of external magnetic fields and the possibility to use this platform to solve some of the limitations such as the low efficiency in lymphocyte trafficking, that some current antitumor immunotherapies present.

\section{The Interaction between MNPs and Lymphoid Cells}

In spite of the attractiveness of MNP-based targeting of effector cells in ACT, some basic considerations must be fulfilled for these applications to be successful: (i) MNP must not show toxicity towards the lymphoid cells; (ii) lymphoid cells must be able to interact with the nanomaterial; (iii) finally, the nanomaterial must be easy to produce in large amounts so that the numerous immune cells required for ACT can be loaded. The use of the co-precipitation synthesis method, which is simple and easily reproducible and scalable, offers a simple solution to this last point [82].

There are several studies reporting that the toxicity of MNPs depends on their coating, the cell type they are interacting with, the MNP concentration, and the exposure time [83-85]. In general, MNPs do not cause notable toxicity in different immune cell types, with high cell viability percentages often observed [86]. MNP toxicity usually occurs mainly when high doses and prolonged exposure times are used $[87,88]$ or in the presence of certain coatings [89]. Besides, there are several studies demonstrating the low toxicity of MNPs in both human and murine T and NK cell lines and in primary T and NK cells [75,78,80,89-99].

We have, however, observed an increase in the mitochondrial metabolic capacity of these cells after association with MNPs [78]. This could indicate some non-specific activation by MNPs, since an increase in mitochondrial mass and activity is usually related to the activation of T and NK cells [100-102], sometimes due to the presence of reactive oxygen species (ROS) [103], a feature often induced by the presence of MNPs in cellular systems [104,105]. In contrast, this was not observed in expanded murine $\mathrm{NK}$ and activated $\mathrm{CD}^{+} \mathrm{T}$ cells. Since these cells are already in an active state, it is probably more difficult to induce or detect significant changes in this aspect.

Further analyses of the metabolic state of primary $\mathrm{T}$ cells revealed that they had increased mitochondrial respiration and glycolysis in the presence of MNPs [78]. These features could be associated with an activated state in $\mathrm{T}$ cells, since aerobic glycolysis increases during the transition from 
naïve to effector $\mathrm{T}$ cells and the proliferation that takes place after the genetic rearrangement of the $\mathrm{T}$ cell receptor (TCR) [106]. In addition, TEM imaging of primary T cells showed an increased presence of mitochondria after treatment with MNPs (Figure 2). Since these cells are barely metabolically active and present a low number of mitochondria in the early stages, these data indicate that MNPs could promote some metabolic activity in resting lymphoid cells. In line with this observation, Mühlberger et al. observed a slight decrease in the percentage of naïve T cells after MNP treatment, both in resting cells and in polyclonally-stimulated cells, hinting that MNP loading may facilitate T cell activation [81].

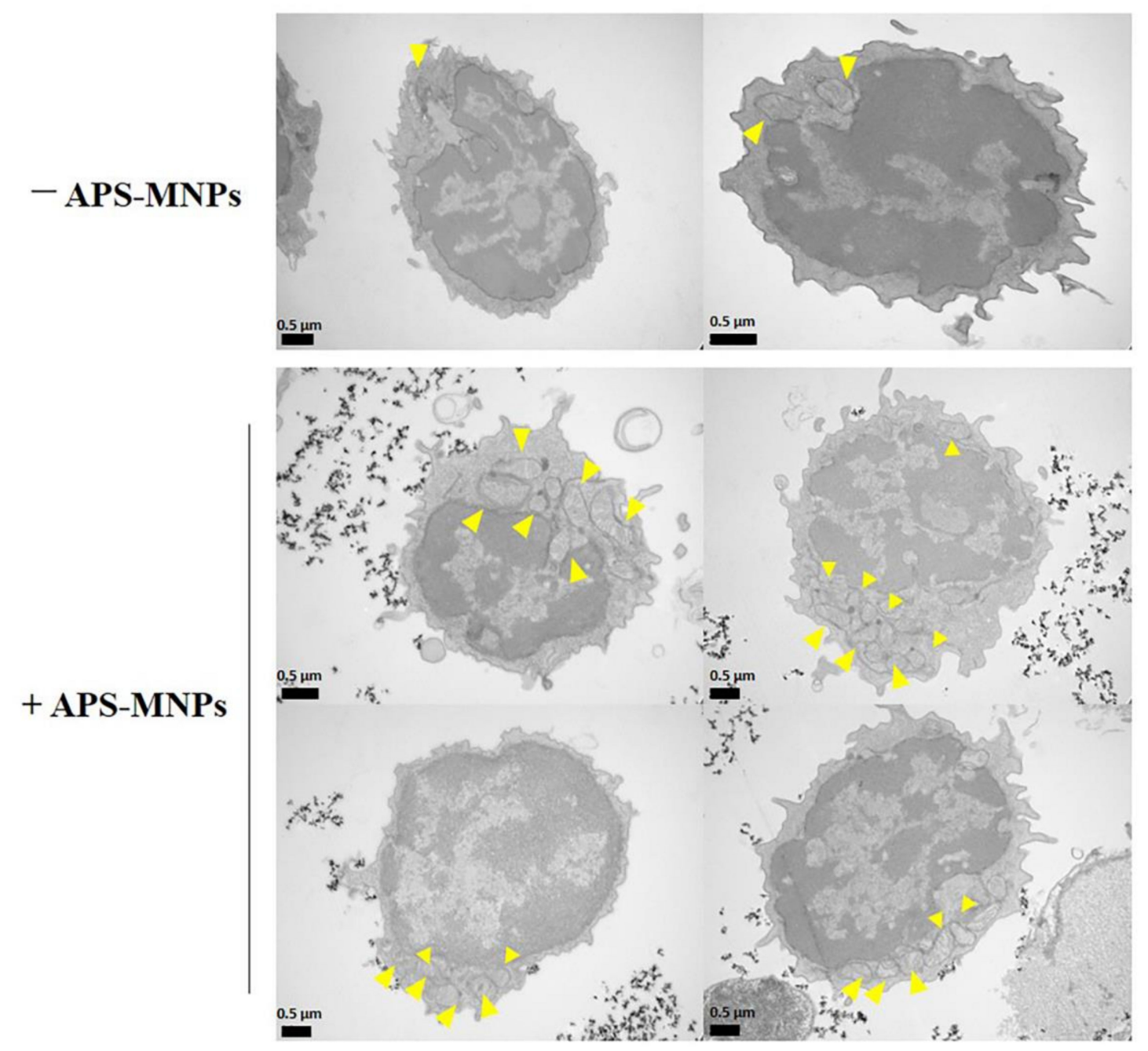

Figure 2. MNP treatment increases the presence of mitochondria in naïve T cells. Representative images obtained by transmission electronic microscopy from murine naïve T cells with MNPs. Arrowheads indicate the mitochondria within the cells. TEM methodology is described in [78].

It has been recently reported that activation of pattern recognition receptors (PRR), which include Toll-like receptor (TLRs) and play a role in the initiation of innate immune responses, can regulate TCR signals and T cell functions [107]. We have previously shown that some MNP coatings such as polyethylenimine (PEI) can trigger macrophage activation through TLR4 signaling [108]. The responsiveness to PRR signaling thus indicates that $\mathrm{T}$ cell activation could be altered by MNP treatment. This is a new research area that will require further investigation.

Studies of the subcellular localization of MNPs showed that, unlike macrophages, mesenchymal or tumor cells, which are able to internalize different types of MNPs [56,70,108-110], lymphoid cells are apparently unable to do so (Figure 3) $[78,79,111,112]$. It is widely described that the uptake of NPs depends on the cell type [113,114]. In the case of lymphoid cells, the MNPs often remained on the cell 
surface, in close contact with the plasma membrane. Lymphoid cells typically have a low phagocytic capacity [115] which would limit the entry of MNPs into the cytoplasm. Indeed, special MNP designs, such as functionalization with RGD (Arg-Gly-Asp) or tat peptides, are often required to improve internalization by these non-phagocytic cells [88,94,116-118]. Other strategies such as transfection or targeting with anti-CD3 antibodies have been attempted to improve MNP labeling of T cells [112,119]. Although effective for lymphoid cell loading, MNP functionalization complicates synthesis and cell handling which would introduce increased variability in MNP-lymphoid cell preparation.

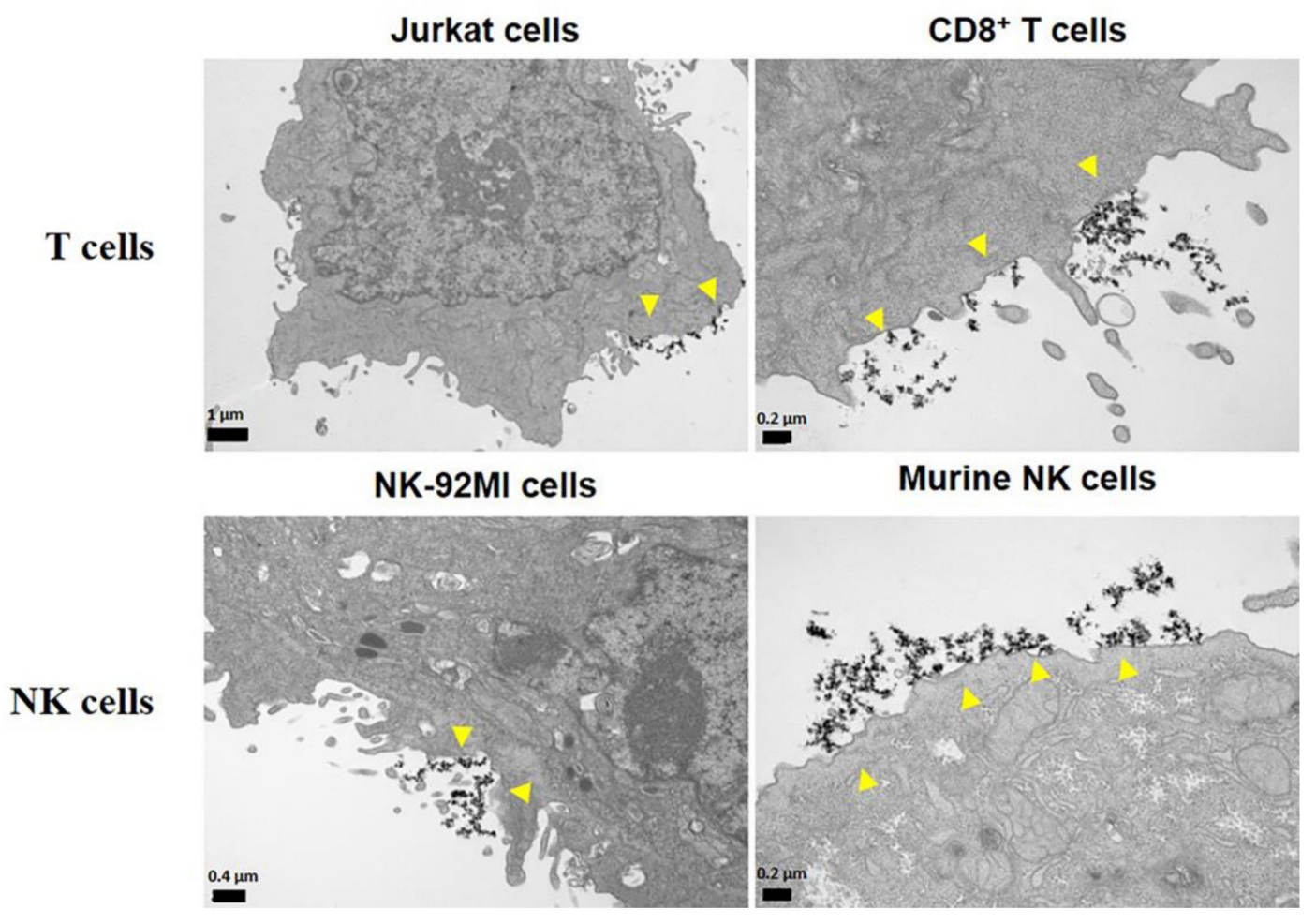

Figure 3. Subcellular localization of the APS-MNPs in different lymphoid cell models. Representative images obtained by transmission electronic microscopy. Arrowheads indicate the MNPs associated with the cell membrane.

Indeed, we and others have described that lymphoid cell loading with minimally functionalized MNPs could be sufficient to achieve magnetic retention [78,79,81]. Our microscopy analysis and iron uptake measurements showed that positively charged MNPs (3-aminopropyl-triethoxysilane (APS)-MNPs) were most associated with all types of lymphoid cells [78]. It is well described that positively charged NPs interact to a greater extent with cell membranes, possibly due to electrostatic interactions [114,120-126]. Muhlberger et al. used negatively charged MNPs and found sufficient association with $\mathrm{T}$ cells to elicit retention by a magnetic field, indicating that MNP interactions with lymphoid cells are not solely dependent on charge [80,81]. The activation status of the lymphoid cells is also likely to affect its capacity to interact with MNPs. We reported that freshly isolated primary T cells associated with MNPs to a lesser extent than activated T cells [78]. This observation corroborated another study that showed that after in vitro stimulation lymphoid cells were able to incorporate more NPs [88].

Overall, most studies evaluating MNP interactions with lymphoid cells indicate that MNPs will be minimally taken up by lymphoid cells. As such, the design of MNPs for loading on lymphoid cells should rely on optimization of the MNP surface charge to increase interaction with the cell plasma membrane (e.g., produce positively charged MNPs that interact with negatively charged membrane lipids). An improved understanding of the mechanics of interaction between plasma membrane and MNPs will surely lead to the design of better MNPs for loading on lymphoid cells in the future. 


\section{In Vitro Functionality in MNP-Loaded Lymphoid Cells}

A sine qua non condition for MNP-based targeting strategies in ACT to be effective is that the effector lymphoid cells retain their function when loaded with MNPs. Several studies consistently indicate that the expression of surface markers is not significantly affected by MNP presence in a wide variety of cells including lymphoid cells [71,72,78,80,96,127-129]. It thus appears that minimally functionalized MNP (i.e., with a simple chemical coating that allows stable colloidal suspension) do not significantly alter the activity of lymphoid cells.

There are, however, surprisingly few studies systematically assessing the effect of MNPs on the multifaceted functionality of effector lymphoid cells. It has been described in in vitro studies for both human and murine $\mathrm{T}$ cells that their proliferation to specific antigens, their cytotoxic capacity against certain cell targets and their cytokine production were not affected by MNP treatment $[95,96,130,131]$. Our studies which looked at multiple parameters to assess T cell functionality after MNP treatment confirmed these findings [78]. Studies also showed that MNP-treated effector T cells maintain their cytotoxic and antitumor activity in vivo and can infiltrate the tumor without apparent problem [94,132]. However, defects in the cytolytic capacity and cytokine production of these cells have also been described, but only in the presence of very high doses of MNPs [88]. Another study showed that dimercaptosuccinic acid (DMSA)-coated MNPs altered cytokine induction and affected the Kv1.3 channel activity in Jurkat cells [133]. This indicates that, similar to other cell types, MNP treatment of lymphoid cells has the potential to interfere with redox activity. Overall, most studies indicate that MNPs association with effector $\mathrm{T}$ cells does not significantly alter $\mathrm{T}$ cell functions.

Only few studies have evaluated MNP effects on NK cells, and most have only addressed this question using human NK cell lines such as NK-92 or KHYG-1. These studies show that NK cell lines preserve their cytolytic capacity in vitro and are able to migrate and infiltrate the tumor similarly to cells not associated with MNPs in vivo [75,97-99,134,135]. Our group recently reported the effect of MNP treatment in several functional aspects of NK cell biology in two NK cell models: a human NK cell line and primary murine NK cells [79]. NK cell recognition of its target is mediated by a range of receptors capable of detecting their ligand expressed in transformed/stressed/infected cells, which leads to cytotoxic responses and/or cytokine production by this effector cell [136]. For NK cell effector functions to take place, the NK cell needs to first conjugate to its target so that an immunological synapse forms to mediate the NK cell cytotoxic responses. In the case of cytokine responses, target recognition should lead to the activation of signaling pathways that result in cytokine production.

MNP presence on the cell membrane of NK or T cells did not affect the effector cell conjugation capacity to target cells in two-color flow cytometry [77,79]. Since MNP can affect cytoskeleton remodeling [137-140], we also assessed by confocal microscopy the formation and polarization of the microtubule organizing center (MTOC) in the synapse between primary NK cell and target cells (Figure 4). No defects in the NK cell MTOC were observed, indicating that MNP-loaded NK cells can conjugate normally to their target cells and form an immunological synapse that would allow effector functions to be triggered.

NK cell-mediated killing of target cells is usually mediated by a process called degranulation that refers to the release of lytic granules containing enzymes that mediate target cell killing. Measuring this process can be used as a surrogate for the cytotoxic capacity of NK cells (and cytotoxic T lymphocytes) [141]. We found that MNP treatment increased in a dose-dependent manner the spontaneous degranulation of NK cells [79], but not of $\mathrm{CD}^{+} \mathrm{T}$ cells [77]. The degranulation of MNP-loaded NK cells after stimulation also increased compared to unloaded cells, but this was quantitatively similar to the increase in baseline degranulation levels. We also observed increased degranulation in MNP-loaded $\mathrm{CD}^{+} \mathrm{T}$ cells when compared to unloaded cells in presence of antigen. These findings indicate that degranulation could be enhanced by the presence of MNP on the surface of cytotoxic cells. In spite of this, an increase in cytotoxicity towards target cells was not detected as both MNP-treated NK cells and T cells could lyse target cells similarly to untreated cells $[77,79]$. 
Other reports also indicate that NK cell MNP treatment does not alter the cytotoxic ability of these cells $[75,88,96,98,132,134]$.

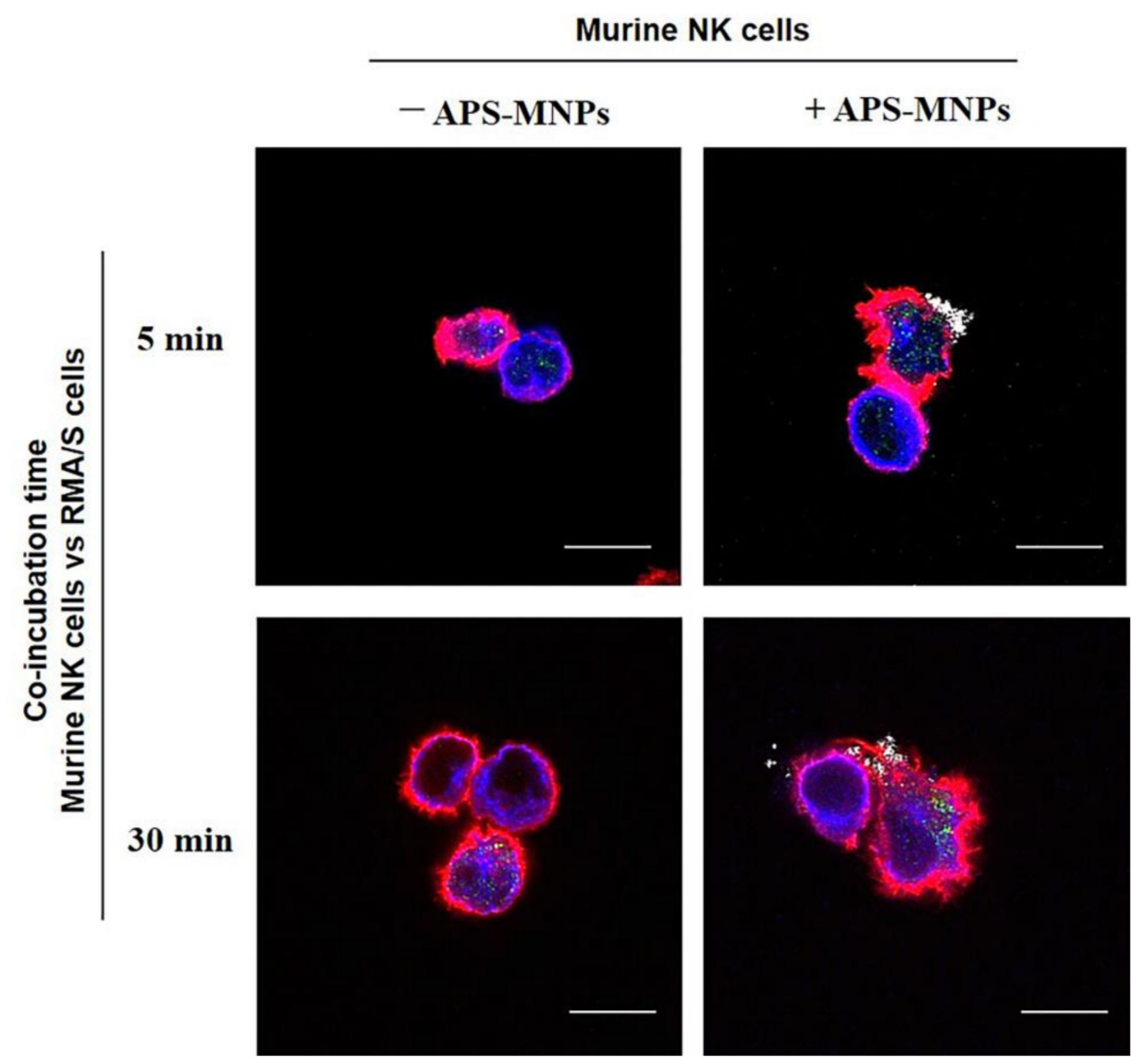

Figure 4. Conjugation of murine NK cells with the RMA/S cell target in presence of MNPs. NK cells were treated with MNPs (+ APS-MNPs) or left untreated (- APS-MNPs) and incubated with RMA/S target cells for different lengths of time. Representative images of their conjugation at different incubation times, acquired by confocal microscopy (actin (red), microtubules (blue), perforin (green), MNPs (gray)). Scale: $10 \mu \mathrm{m}$. Dark-field confocal imaging is described in [78] and conjugation technique in [79].

Another important functional aspect of NK cell biology is their capacity to produce cytokines that modulate immunity [142]. Among those, interferon (IFN)- $\gamma$ is one of the most important pro-inflammatory cytokines produced by this type of cell [143]. We and others have reported that MNP treatment did not affect IFN- $\gamma$ production in human or murine NK cells, as well as CD8 ${ }^{+}$ T cells, in response to various stimuli $[77,79,88,95,131]$. NK cells have been reported to produce other cytokines and chemokines that modulate immunity, such as IL-5, IL-10 or CCL5 for instance [144-147]. Assessing the production of these cytokines in the presence of MNPs would be useful in the future to better understand the capacity that MNPs could have in altering alternative NK cell responses to stimuli.

NK cells are continuously circulating and are recruited from the circulation to the tumor by a five-step sequential process that involves: (1) cell rolling on the endothelium followed by (2) a chemokine-activation step that results in (3) activation and full adhesion to the endothelium. The adhered cells then (4) migrate laterally to find a site where they can penetrate the endothelium to finally (5) cross the endothelial barrier $[35,36]$. These characteristics are integral to NK cell functionality, and it is therefore important to assess MNP effects on these mechanisms. We reported that NK cells treated with APS-coated MNPs could still adhere and transmigrate through an endothelial monolayer [79]. In fact, the presence of MNPs in the cell membrane occasionally increased adhesion to 
endothelial cells. This could be due to the MNP exposition on the membrane of NK cells that could ease their interaction with the endothelium due to the MNP charge. These results are in line with several other studies which show that both $\mathrm{T}$ and NK cells associated with MNPs could migrate and infiltrate the tumor tissue in vivo as effectively as untreated cells $[94,96-99,132,134]$. Overall, it appears that MNP treatment of $\mathrm{T}$ and NK cell produce minimal alterations in their function. MNP presence on the cell surface could slightly increase basal degranulation of cytotoxic cells, but other functions such as cytotoxicity, cytokine production or transmigration through the endothelium seem to remain intact. Although it remains critical to evaluate the activity of each MNP preparation on lymphoid cells, most studies indicate that the effects of minimally functionalized MNPs could be negligible on these cell populations, thus opening the gate to MNP use as magnetic targeting agents for lymphoid cells.

\section{In Vitro and In Vivo Magnetic Retention of MNP-Loaded Immune Cells}

\subsection{In Vitro Magnetic Retention}

The chemotactic response is critical and essential for the trafficking of lymphoid cells through the different tissues and regions where they are required. We reported that the association of lymphoid cells with MNPs slightly decreased in some cases the response by these cells to a chemotactic gradient. This effect could be corrected by the application of an EMF in the same direction as the chemotactic gradient [78]. Similar results have been described in DCs [69,72], indicating that the loading of immune cells with MNPs could affect chemotaxis. In vitro "under agarose" migration assays, which allow the study of polarized $\mathrm{T}$ cell behavior within a confined system, showed that the presence of MNPs and EMF affected cell migration (Figure 5). MNP-loaded T cell mobility was reduced when compared to unloaded counterparts even in the absence of EMF (Figure 5B). EMF application further reduced MNP-loaded cell migration in these studies, and this effect was dependent on the distance at which the EMF was applied. EMF applied at closer proximity to the migration system (i.e., equivalent to increasing the magnetic field) limited MNP-loaded T cell displacement further than when placed at distal location (Figure 5). Curiously, a similar effect was also detected in unloaded T cells, albeit to a lower extent. Several factors could explain the reduction in migration produced by MNP loading. On the one hand, there are several studies showing that the presence of MNPs in cells can affect the rearrangement of the actin cytoskeleton and microtubules, thus limiting their motility [137-140]. Although in these experiments, the MNPs were associated with the plasma membrane, and not in the cytoplasm, so the decrease in migration is unlikely due to a direct effect of MNPs on the actin machinery. On the other hand, it has been observed that the presence of magnetic components such as MNPs and/or the exposure to moderate static magnetic fields can influence biological systems mainly through alterations of the transmembrane ionic fluxes, such as the calcium ion flux [148-150]. It is known that changes in intracellular calcium levels govern rapid cytoskeleton remodeling, which is key in T cell activation [151], as well as T cell migratory response to chemokine gradients or their extravasation, among other processes [152]. This could also explain this "non-specific" retention effect on unloaded cells and will be discussed in a subsequent section of this review.

MNP-based retention of lymphoid cells in the organism requires balancing the strength of the EMF with the flow forces that are applied to these circulating cells. In vivo MNP-based retention will therefore only be effective if lymphoid cells can be retained in a specific location in spite of the presence of these flow forces. We showed that a minimum amount of MNPs needs to be associated with the cells for them to be retained by an EMF. Magnetic retention increased with the amount of MNPs associated with the cells as well as with the force of the magnetic gradient applied [78]. Others also found that similar amounts of MNP were necessary to load lymphoid cells to magnetically retain them $[80,81]$. Indeed, additional studies confirm that three parameters are critical for magnetic targeting: (1) amount of MNP associated to cells; (2) force of the magnetic gradient; (3) length in time of EMF application [73,153]. 
A
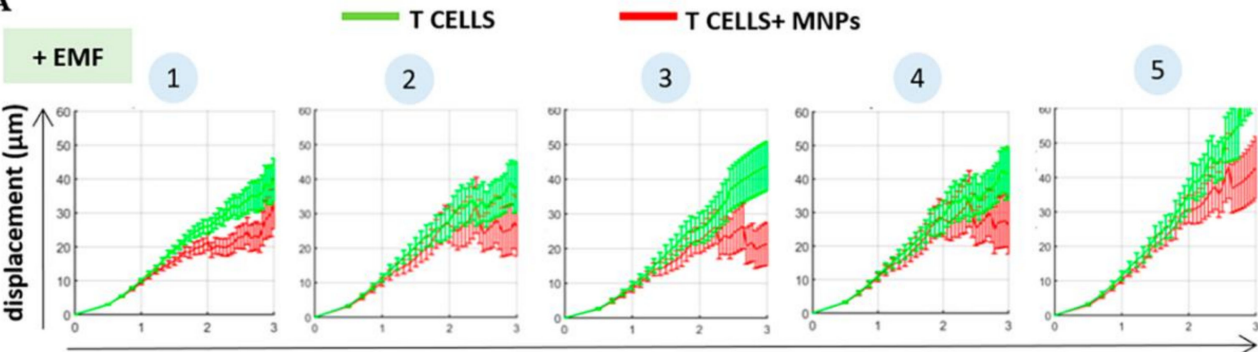

Square root of time $\left(\min ^{1 / 2}\right)$

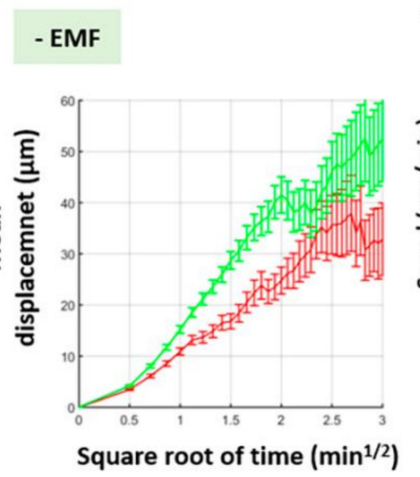

C

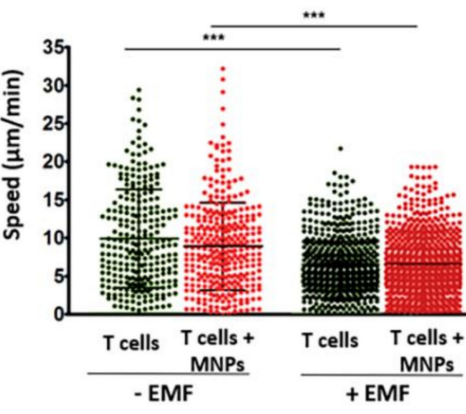

D

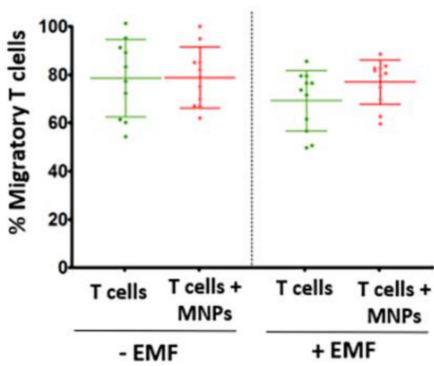

Figure 5. Analysis of the migratory capacity of murine $\mathrm{T}$ cells after association with MNPs and in presence of an EMF, in in vitro "under agarose" migration assays. Coverslips were coated with recombinant murine Intercellular Adhesion Molecule 1 (ICAM-1) and CCL21 and overlaid with agarose. Primary murine $\mathrm{T}$ cells were labelled with CellTracker orange dye (Invitrogen), injected under the agarose layer with a micropipette and allowed to polarize for $30 \mathrm{~min}$ prior to the EMF application. Five positions ( 1 to 5 ) were selected with the microscope at increasing distance of the applied magnet (position 1 being the closest to the magnet and position 5 being the furthest from the magnet), and T cell movement was tracked over time. Mean displacement versus time graphs of $\mathrm{T}$ cells in the "under agarose" assay (A) at increasing distances from an EMF and (B) in the absence of an EMF. On one hand, these results indicate that MNP treatment by itself produces alterations in the migratory capacity of murine T cells, which show a reduction in the displacement along the time compared to untreated cells. On the other hand, EMF impairs migration in both MNP-treated and untreated murine T cells in a distance-dependent manner. Quantification of (C) cell speed and (D) percentage of cells that migrate in all conditions after analyzing the movies using Imaris software. The results shown (mean \pm SD) are representative of two independent experiments. Student's t-test, ${ }^{* * *} p<0.001$. These results show that both MNP treatment and EMF application reduce the velocity of murine T cells. However, no differences in the number of cells that was able to migrate were found in the different conditions.

\subsection{In Vivo Retention of MNP-Loaded Cells in Lymphoid Tissues}

Magnetic in vivo tissue targeting with MNP-loaded cells has been reported, but they usually involved other cell types, mostly macrophages or mesenchymal cells [69-74]. Recent reports extend to lymphoid cells the application of magnetic targeting to specifically promote cell accumulation-an area of research often overlooked until now $[75,77,78]$. We reported that EMF application favored the retention of MNP-loaded T cells in the lymph node (LN), confirming that magnetic targeting is achievable in vivo with MNP-loaded lymphoid cells [78]. Interestingly, the mere presence of MNPs on the cell surface increases the retention of these cells in secondary lymphoid organs. However, $\mathrm{T}$ cells associated with MNPs did not show a preferential location or distribution towards a specific lymphoid organ in the absence of EMF. This preferential accumulation of MNP-associated T cells in lymphoid tissues appears to be the result of decreased in vivo cell mobility.

Multiple factors could explain the increased retention of MNP-loaded cells in secondary lymphoid organs. It has been previously described that cells associated with MNPs present a greater tendency 
to aggregate [154]. It appears that MNPs could act as a link that facilitates cell-to-cell interactions, probably due to their electrostatic charges. This phenomenon could contribute to the reduced speed of MNP-loaded cells in LN. Indeed, in vivo multiphotonic microscopy studies showed that T cells associated with MNPs have a reduced speed in the LN [78]. This could contribute to the increased retention of these MNP-associated cells in lymphoid tissues, even in the absence of an EMF, as the reduction in speed could prolong their interaction with tissue vasculature and facilitate retention.

EMF application could also affect cell speed. It has been demonstrated that moderate static magnetic fields can influence biological systems primarily through alterations at the level of transmembrane ionic fluxes and of the fluidity of the phospholipids that constitute cell membranes [148-150]. Microscopy studies of calcium flux showed that maximum and mean responses were reduced in murine $\mathrm{T}$ cells after MNP treatment, which could indicate that the presence of magnetic components in cell membranes could affect calcium signaling [78]. This fact is important since it has been described that the magnitude and duration of calcium fluxes influence the basal velocity of T cells in LNs [151]. A reduced amplitude in intracellular calcium peaks related to arrest, or more limited T cell movement, in order to favor their interaction with the stroma and with other leukocytes $[155,156]$. Therefore, since the magnitude and duration of intracellular calcium levels control $\mathrm{T}$ cell responses, EMF application could affect essential biological aspects of these cells such as activation [151] or migration in response to chemotactic gradients [157]. These are important consideration that will need addressing for using MNP as directional agents in ACT.

It has also been reported that the biological effects caused by a magnetic field depend more on the magnitude of the magnetic gradient than on the strength of the field [158]. Indeed, when two EMF were used around an LN (thus increasing the magnetic gradient) we observed a further reduction in $\mathrm{T}$ cell speed in the LN [78]. This phenomenon also occurred with unloaded T cells, indicating that strong magnetic gradient could alter T cell circulation speed in lymphoid organs. Analyses of the cell trajectories in these experiments indicated that the presence of MNPs did not significantly alter the path of the lymphocytes within the LN when an EMF was applied, although a study in greater depth, at longer times, and with a higher EMF could be necessary to detect changes in the trajectory due to the tissue complexity of the LN.

In a pilot study, we loaded dendritic cells (DCs) with MNPs, as these cells have a greater capacity for MNP internalization than T cells $[69,72,159,160]$ and thus a greater potential for attraction to an EMF (Figure 6). This also allowed us to determine whether MNP internalization in immune cells promoted the same retention phenomena in secondary lymphoid organs that is described for membrane-loaded $\mathrm{T}$ cells. As for T cells, a greater number of DCs loaded with MNPs were found in the popliteal LN. It thus appears that the presence of MNPs can increase the retention or infiltration of immune cells within lymphoid organs independently of the MNP cellular location (Figure 6A). A decrease in cell velocity in LN was also observed for MNP-loaded DCs, but not for unloaded cells (Figure 6B), and this appears to be independent of the presence of EMF in our experimental setting. Several reports have shown that MNP-labeled DCs are retained in LN when adoptively transferred [71,161]. Retention of MNP-loaded DCs in LN could therefore be favored by the reduced speed these cells display when loaded with nanomaterial. Cell trajectory analysis in LN showed a slight increase in DC migration towards the EMF side (Figure 6C). Multiple parameters could explain the reduction in the speed of MNP-loaded DCs in the LN. MNP presence can affect the cytoskeleton reorganization after internalization [137-140] and EMFs have the potential to alter transmembrane ion fluxes and/or the membrane phospholipids organization among other things [148-150]. These factors could alter the activation status and migratory capacity of DCs, and more in-depth studies would help to better understand the in vivo behavior of DCs associated with MNPs and in the presence of an EMF. 


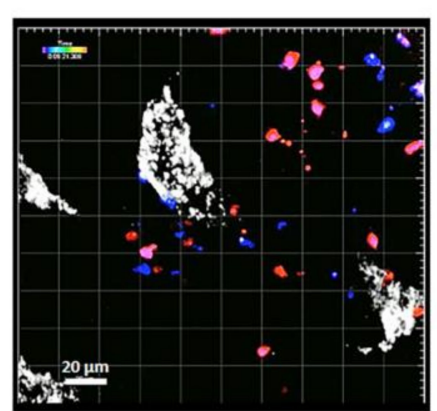

+ EMF

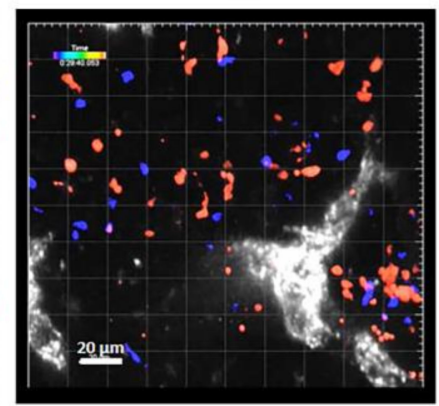

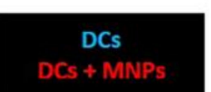

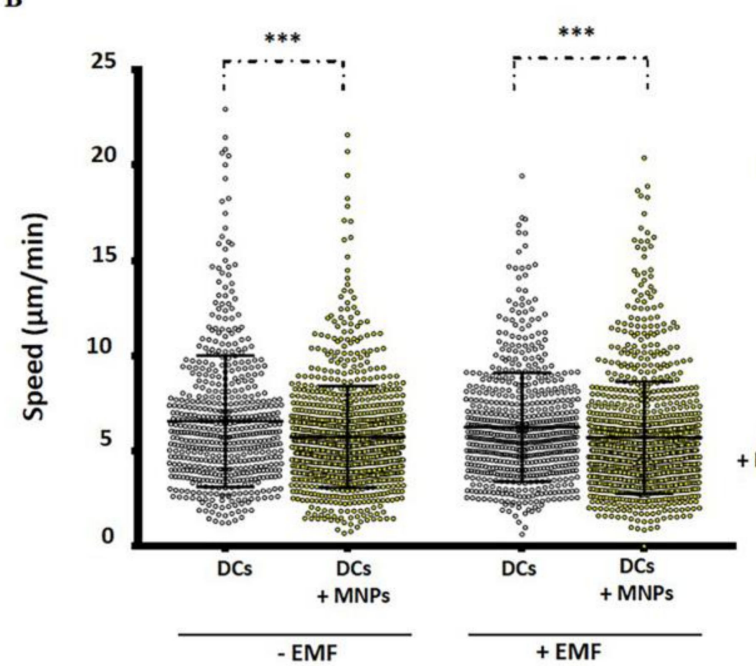

C
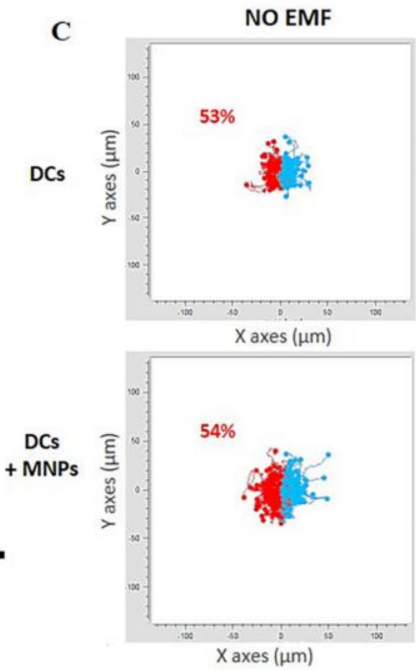

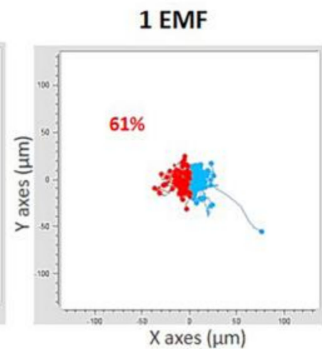

Xaxes ( $\mu \mathrm{m})$

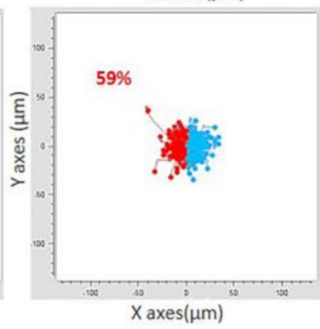

Figure 6. In vivo behavior of MNP-loaded or unloaded murine DCs in the popliteal LN in the presence or absence of an EMF. (A) Representative captures of multiphoton microscopy movies obtained in presence or absence of EMF (blue: MNP-free DCs, red: MNP-associated DCs, gray: high endothelial venules (HEVs)). (B) Quantification of cell speed after movie analysis using Imaris software. The results shown (mean $\pm \mathrm{SD}$ ) are representative of two-three independent experiments. Student's t-test, ${ }^{* * *} p<0.001$. (C) Paths followed by MNP-treated or untreated DCs inside the LN during the multiphoton microscopy assays in the absence or presence of EMF placed on the left (overall DC displacement to the left in red; to the right in blue), analyzed with the software provided by Ibidi (Chemotaxis and Migration tool). The methodology and ethic committee permits for these experiments are detailed in [78].

Overall, it appears that, independent of the presence of MNPs on the cell surface or intracellularly, loading of immune cells is likely to increase the retention time in lymphoid organs. It is worth noting that delivery routes of DC-based vaccines that target LNs are associated with improved antitumor effects [162,163]. This characteristic of MNP-loaded immune cells could therefore be exploited for therapeutic ends. Similarly, T cells associated with MNPs can be magnetically retained in the LNs and this could potentially be used to modulate $\mathrm{T}$ cell activity in these lymphoid organs to control pathology. For example, in a model of autoimmune ovarian disease, the accumulation of regulatory $\mathrm{T}$ cells in the ovary-draining LN counteracted the pathogenic immune response and inhibited the development of the disease [164]. Conversely, the retention of DCs in the LN could also be useful in cancer vaccination to trigger specific tumor antigen responses. Several studies have explored strategies to accumulate DCs in the LNs using MNPs [69,71] some of which improve immunotherapy [71]. The duration of the interaction between DCs and T cells in the LN modulates the specificity and strength of the T cell response [165-169], so the decrease in the speed of MNP-loaded T cells and DCs that we report in LNs, could increase their interaction time and consequently trigger more powerful $\mathrm{T}$ cell responses with greater affinity. This MNP-based strategy could also be applied to other regions of interest, such as a 
tumor, with the aim of increasing the residency time of effector cells in the targeted tissue and thereby enhancing antitumor immune responses.

\section{In Vivo Magnetic Tumor Targeting of Lymphoid Cells: Not So Straightforward}

Most studies concur that MNP loading does not cause alterations or defects in lymphoid cell functions. Thus, using this loading strategy to direct cells to a site of interest with an EMF appears as an attractive and feasible approach to improve ACT effectiveness. Surprisingly few reports have, however, employed this strategy to improve ACT in a tumor context. Jang et al. demonstrated using the NK cell line, NK92-MI, labeled with fluorescent MNPs, that application of an EMF could enrich adoptively transferred cells in the vicinity of the tumor although they did not study their effects on tumor growth [75]. We have recently contributed to this field by assessing the magnetic retention of antigen-specific $\mathrm{CD} 8^{+} \mathrm{T}$ cells in vivo in a tumor model and determining whether tumor magnetic targeting improved ACT-based treatment. We used a murine syngeneic tumor model, where the implanted tumor cells express ovalbumin (OVA) as a surrogate tumor antigen which can be specifically recognized by MHC class I-restricted, OVA-specific CD8 ${ }^{+} \mathrm{T}$ cells (OT-I cells). In this model, tumor growth is reduced by OT-I CD8 ${ }^{+} \mathrm{T}$ cell infiltration $[94,170,171]$. This allowed us to examine whether the application of an EMF over the tumor could favor the retention of MNP-loaded OT-I CD8 ${ }^{+} \mathrm{T}$ cells in that region. Surprisingly, we were unable to increase the accumulation of antigen-specific $\mathrm{CD} 8^{+} \mathrm{T}$ cells at the tumor site in our experimental setting [77]. In fact, EMF application appeared detrimental to therapy with MNP-loaded antigen-specific $\mathrm{CD} 8^{+} \mathrm{T}$ cells. Adoptive transfer of MNP-loaded antigen-specific $\mathrm{CD} 8^{+} \mathrm{T}$ cells did nonetheless achieve the same therapeutic effect as unloaded cells in the absence of an EMF, indicating that MNP-loading did not impair normal migration to the tumor site. Other ACT studies using MRI to visualize OVA-specific CD8 ${ }^{+} \mathrm{T}$ cells loaded with MNPs also found that these cells maintain their baseline tumor homing activity [94,132]. Subsequent tissue analysis revealed a greater infiltration of MNP-loaded antigen-specific CD8 ${ }^{+} \mathrm{T}$ cells in the tumor-draining LN of EMF exposed mice. Additionally, these cells presented a higher activation status. These results indicate that EMF exposure can favor the retention of the transferred antigen-specific $\mathrm{CD}^{+} \mathrm{T}$ cells in the tumor-draining $\mathrm{LN}$ instead of the tumor. This is an important finding for the field, as it illustrates that magnetic forces will compete with a multitude of biological factors that can interfere with the delivery of lymphoid cells to their intended destination. Indeed, because of the proximity between the LN and the tumor, the exposure to an EMF could have favored the retention of these MNP-loaded cells in the LN, a more suitable niche for T cells than the tumor microenvironment. The observation that the antigen-specific $\mathrm{CD} 8^{+} \mathrm{T}$ cells in this $\mathrm{LN}$ present a more activated phenotype confirms that their residency time in this tissue was increased [77], as longer T cell interactions in secondary lymphoid tissues usually correlated with increased activation. The application of one or more smaller magnets such as "magnetic needles", which provide a more focused magnetic field in a limited area [172], could be used to improve specific infiltration into the tumor and not in the LN. Another approach to increase magnetic targeting was recently proposed by Pai et al., which showed that dynamically programmable magnetic fields improved MNP-labeled CAR-T cells' spatial targeting [111]. These data highlight the complexity of translating in vitro observation to in vivo systems, in which a plethora of physical and biological processes will compete with magnetic forces.

Our report indicates that adoptively transferred MNP-loaded antigen-specific T cells could become trapped in LNs proximal to the tumor mass and this could be problematic for effector cell delivery at the tumor site. It is therefore of great interest to try to understand why this $\mathrm{T}$ cell retention occurred in the draining LN rather than in a tumor that presented a greater magnetic field. As previously discussed, the reduction in speed of MNP-loaded T cells in LNs could prolong their interaction with the lymphoid tissue vasculature and facilitate their retention. In addition, the tendency of the cells that carry MNPs to aggregate [154] could contribute to the inability to leave the LN.

Besides the physical factors related to the presence of MNPs on these antigen-specific CD8 ${ }^{+} \mathrm{T}$ cells, biological aspects of the LN structure could also favor the retention of these cells. Sphingosine-1- 
Phosphate Receptor 1 (S1PR1) expression on T cells is a master regulator of effector T cell egress from the LN [173-177]. It has been described that after TCR stimulation, the expression of S1PR1 decreases [174], then, a mechanism mediated by the overexpression of the activation marker CD69 complexes with S1PR1, causing its internalization and degradation $[174,178,179]$. This probably increases the interaction time of activated $\mathrm{T}$ cells in the $\mathrm{LN}$, which promotes their differentiation into effector cells, onto which S1PR1 is again upregulated to permit their egress from the LN. Alteration in S1PR1 expression in T cells could therefore limit the capacity of adoptively transferred cells to exit the LN they infiltrated. Furthermore, it has also been described that antigen-specific regulatory $\mathrm{T}$ cells exert their immunosuppressive action in the LNs by promoting, among other things, a decrease in the expression of S1P1R in effector T cells, thereby trapping these cells in the LN [180]. Evaluating the expression of S1PR1 and of other chemokine receptors, such as CCR7 [181], that control T cell migration in adoptively transferred cells would therefore be useful to optimize the migratory profile of transferred MNP-loaded T cells, so that their retention in the tumor is not only promoted by the EMF but also by biological factors such as chemokines.

Specific antigen recognition by the TCR decreases $\mathrm{T}$ cell migration and favors $\mathrm{T}$ cell contacts with the antigen presenting cells (APCs) [182]. T cell activation results in a change in cell polarity that decreases its speed and increases its adhesion capacity, mainly through Lymphocyte function-associated antigen 1 (LFA-1) and other integrin expression [183]. This inhibition in activated $\mathrm{T}$ cell migration is dependent on Rac1 and promotes retention at the site of inflammation and infection [184]. T cell migration within the LN is dependent on the formation of various structures (lamellipodia and uropod) that allow cell displacement, by reorganizing cytoskeleton components $[185,186]$. However, some of these elements can only be mobilized to promote one cellular function, such as the microtubule organizing center (MTOC) that has a different orientation depending on whether the cell is migrating or interacting with APCs [182]. Thus, an imbalance between the formation and relocation of certain cytoskeleton structures can also produce a decrease in migration.

Enhanced interactions with resident LN cells (e.g., macrophages) or even with the LN extracellular matrix due to MNP presence could also play a role in the apparent retention of loaded cells in LNs. For instance, subcapsular and spinal macrophages within the LN are involved in the entrapment of gammadelta $(\gamma \delta) \mathrm{T}$ cells in LNs for long periods of time [187]. In addition, interactions between lymphocytes and the extracellular matrix are usually transient when the lymphocyte has a high migration capacity, since the formation of focal adhesions inversely correlates with the speed of migration [188]. The reduced intranodal speed of transferred $\mathrm{T}$ cells when associated to MNPs could therefore be due in part to their interaction with certain cell types, such as macrophages or reticular fibroblasts, or even with the extracellular matrix [185], thus hampering their correct transit through the LN $[174,189,190]$. Multiple biological factors could therefore contribute to the apparent retention of MNP-loaded T cells in the LN. Retention in the LN is an important issue in ACT, and a better understanding of the mechanism governing the trafficking of adoptively transferred cells will surely improve the efficiency of these therapies, independently of the use of MNPs and EMF to promote accumulation at the site of interest. Modulation of lymphocyte trafficking could also find some applications in the treatment of autoimmune diseases [191]. Indeed, the drug, FTY720, designed to block the egress of autoreactive T cells from LNs to prevent their invasion to inflamed regions, has been approved by the FDA for the treatment of multiple sclerosis [192], illustrating that modulation of $\mathrm{T}$ cell migration has therapeutic potential.

\section{Conclusions and Future Perspectives in the Use of CAR-T Cells}

This review highlights the recent findings on the effects of MNPs on lymphoid cells, their specific targeting through the application of an EMF and the possibility to use this strategy to target transferred cells to the tumor and thus solve one of the main limitations of ACT in cancer. Most studies show that MNP treatment has minimal effects on lymphoid cell functionality in vitro and in vivo $[75,77-79,94,96-99,130-132,134]$. 
Key questions, however, remain unanswered concerning basic biological aspects of the interaction of lymphoid cells with MNPs. We have discussed at length the decrease in speed of lymphoid cells when associated to MNP in the LN, which is likely due to a combination of biological and physical factors that increase the interaction time of MNP-loaded lymphoid cells with the resident cells of the secondary lymphoid tissues. Another yet unexplored area would be to evaluate the adjuvancy and metabolic effects that MNPs could have on effector T or NK cells. MNPs have been reported to interact with PRR in immune cells $[108,193,194]$ and we found that mitochondrial metabolism increased in T cells treated with MNPs. Designing MNPs that would favor T cell activation as well as promoting their magnetic targeting could represent an attractive perspective for the future of ACT therapy in cancer. Indeed, the use of engineered MNP as a platform for $\mathrm{T}$ cell activation and enrichment has proved successful [195].

Although lymphoid cell retention in the LNs due to MNP loading and EMF application can be problematic for antitumor therapy, this phenomenon could prove useful in certain autoimmune pathologies to prevent effector cell migration towards the affected tissue. Accumulation of tumor-specific $\mathrm{CD}^{+} \mathrm{T}$ cells in the tumor-draining $\mathrm{LN}$ may have an upside as it could protect against metastasis spreading via the LNs. ACT could also be combined with other strategies, such as those aimed at the normalization of the tumor vasculature, to improve treatment efficiency. These therapies could further facilitate the infiltration of the transferred cells within the tumor by improving the structure as well as the function of the tumor vessels.

Since it is difficult to obtain and/or generate/expand patients' tumor-infiltrating lymphocytes and tumor-specific $\mathrm{T}$ cells in sufficient numbers, the use of effector $\mathrm{T}$ or NK cells modified with engineered TCRs or chimeric antigen receptors (CAR) has become a powerful approach within ACT therapies. Engineered TCR therapy involves the introduction in T cells of cloned TCRs with high affinity for a TAA, thus redirecting T cell activity towards cancer cells carrying the TAA. For example, there are specific cloned TCRs against the Melanoma Antigen Recognized by T cells 1 (MART-1) that can be introduced into human lymphocytes to specifically treat patients with positive tumors for this antigen [196]. Unfortunately, one of the main tumor escape mechanisms to evade the activity of T cells is the decrease in major histocompatibility complex (MHC) molecule expression [197], thereby limiting antigen presentation and antitumor responses induced by TCR-engineered cells. CARs would solve this immunoevasion problem since $\mathrm{T}$ cells are endowed with artificial receptors specific for a surface tumor protein or antigen [198]. There are currently a variety of studies demonstrating CAR-T cell use in antitumor immunotherapy [199-202]. Specifically, numerous clinical trials using T-cells with CARs directed against CD19 in B-cell lymphomas have shown remarkable and lasting responses [203], and the FDA has approved two of these therapies in 2017 for clinical use. Regarding the use of NK cells in ACT therapies, modifications of NK cells, such as the NK-92 cell line, with CARs in order to overcome some tumor escape mechanisms and to direct NK cell activity more specifically have been developed [204,205]. The use of MNPs together with localized EMFs could improve the targeting of these genetically modified lymphoid cells and enhance antitumor immune response. An example of this type of strategy has been recently published by Nie et al. In this work magnetic nanoclusters loaded with PD-1 antibody and bound to effector T cells were used as a platform to magnetically recruit effector T cells and PD-1 antibody simultaneously to the tumor with MRI guidance [206] resulting in inhibition of tumor growth in a murine model.

It would also be important for the application of this nanotechnology to develop synthesis methods that could be easily scaled-up and standardized as well as performed in a hospital clean room to allow for their implementation in clinical settings. Clinical-grade MNPs could be prepared together with the CAR-T cells in compliance with Good Manufacturing Practices (GMPs) and their combined use could therefore be more easily translated to clinical practice. The microwave method for MNP production represents a promising approach to this issue as it produces highly uniform nanoparticles in particularly short times with better reproducibility than other strategies and without using toxic materials [207]. 
As exposed in this review, nanotechnological solutions have the capacity to improve ACT therapy. Controlling immune cell traffic using MNP and EMF would have great potential in the treatment of a diversity of diseases. However, much effort remains in this area to fully understand the mechanisms that govern the interaction of MNP with lymphoid effector cells, and to further apply this technology in vivo where magnetic forces will compete with the complex biological regulation of lymphoid cell migration.

Author Contributions: Writing—review and editing L.S.-O., J.M.R., D.F.B.; Funding acquisition, D.F.B. All authors have read and agreed to the published version of the manuscript.

Funding: This research was supported in part by Grants from the Spanish Ministry of Economy, Industry and Competitiveness (SAF-2014-54057-R and SAF-2017-82223-R to Domingo F. Barber). Laura Sanz-Ortega received a predoctoral FPU Grant (FPU13/05037) from the Spanish Ministry of Economy, Industry and Competitiveness. José Manuel Rojas is supported by the European Commission-funded VetBioNet INFRAIA-731014 project.

Acknowledgments: We thank members of the laboratories led by Domingo F Barber (CNB-CSIC, Madrid) and María del Puerto Morales (ICMM-CSIC, Madrid) for helpful comments and discussion. The authors also want to thank J.V. Stein, A. Marcos and F. Thelen (Theodor Kocher Institute) for their technical support in the "under agarose" and multiphotonic microscopy assays (Figures 5 and 6).

Conflicts of Interest: The authors declare no conflict of interest.

\section{References}

1. Caspi, R.R. Immunotherapy of autoimmunity and cancer: The penalty for success. Nat. Rev. Immunol. 2008, 8, 970-976. [CrossRef] [PubMed]

2. Motz, G.T.; Coukos, G. Deciphering and reversing tumor immune suppression. Immunity 2013, 39, 61-73. [CrossRef] [PubMed]

3. Mellman, I.; Coukos, G.; Dranoff, G. Cancer immunotherapy comes of age. Nature 2011, 480, 480-489. [CrossRef] [PubMed]

4. Blattman, J.N.; Greenberg, P.D. Cancer immunotherapy: A treatment for the masses. Science 2004, 305, $200-205$. [CrossRef] [PubMed]

5. Munhoz, R.R.; Postow, M.A. Recent advances in understanding antitumor immunity. F1000Research 2016, 5, 2545. [CrossRef]

6. Dustin, M.L. Cancer immunotherapy: Killers on sterols. Nature 2016, 531, 583-584. [CrossRef]

7. Kakimi, K.; Karasaki, T.; Matsushita, H.; Sugie, T. Advances in personalized cancer immunotherapy. Breast Cancer 2016, 24, 16-24. [CrossRef]

8. Mackensen, A.; Meidenbauer, N.; Vogl, S.; Laumer, M.; Berger, J.; Andreesen, R. Phase I study of adoptive T-cell therapy using antigen-specific CD8+ T cells for the treatment of patients with metastatic melanoma. J. Clin. Oncol. 2006, 24, 5060-5069. [CrossRef]

9. Dudley, M.E.; Rosenberg, S.A. Adoptive-cell-transfer therapy for the treatment of patients with cancer. Nat. Rev. Cancer 2003, 3, 666-675. [CrossRef]

10. Yee, C. Adoptive T cell therapy: Addressing challenges in cancer immunotherapy. J. Transl. Med. 2005, 3, 17. [CrossRef]

11. Rosenberg, S.A.; Mulé, J.J. Immunotherapy of cancer with lymphokine-activated killer cells and recombinant interleukin-2. Surgery 1985, 98, 437-444. [PubMed]

12. Rosenberg, S.A.; Lotze, M.T.; Muul, L.M.; Chang, A.E.; Avis, F.P.; Leitman, S.; Linehan, W.M.; Robertson, C.N.; Lee, R.E.; Rubin, J.T.; et al. A progress report on the treatment of 157 patients with advanced cancer using lymphokine-activated killer cells and interleukin-2 or high-dose interleukin-2 alone. N. Engl. J. Med. 1987, 316, 889-897. [CrossRef] [PubMed]

13. Rosenberg, S.A.; Yang, J.C.; Sherry, R.M.; Kammula, U.S.; Hughes, M.S.; Phan, G.Q.; Citrin, D.E.; Restifo, N.P.; Robbins, P.F.; Wunderlich, J.R.; et al. Durable complete responses in heavily pretreated patients with metastatic melanoma using T-cell transfer immunotherapy. Clin. Cancer Res. 2011, 17, 4550-4557. [CrossRef] [PubMed]

14. Tran, K.Q.; Zhou, J.; Durflinger, K.H.; Langhan, M.M.; Shelton, T.E.; Wunderlich, J.R.; Robbins, P.F.; Rosenberg, S.A.; Dudley, M.E. Minimally cultured tumor-infiltrating lymphocytes display optimal characteristics for adoptive cell therapy. J. Immunother. 2008, 31, 742-751. [CrossRef] 
15. Zhou, J.; Dudley, M.E.; Rosenberg, S.A.; Robbins, P.F. Persistence of multiple tumor-specific T-cell clones is associated with complete tumor regression in a melanoma patient receiving adoptive cell transfer therapy. J. Immunother. 2005, 28, 53-62. [CrossRef] [PubMed]

16. Robbins, P.F.; Dudley, M.E.; Wunderlich, J.; El-Gamil, M.; Li, Y.F.; Zhou, J.; Huang, J.; Powell, D.J.; Rosenberg, S.A. Cutting edge: Persistence of transferred lymphocyte clonotypes correlates with cancer regression in patients receiving cell transfer therapy. J. Immunol. 2004, 173, 7125-7130. [CrossRef]

17. Klebanoff, C.A.; Gattinoni, L.; Torabi-Parizi, P.; Kerstann, K.; Cardones, A.R.; Finkelstein, S.E.; Palmer, D.C.; Antony, P.A.; Hwang, S.T.; Rosenberg, S.A.; et al. Central memory self/tumor-reactive CD8+ T cells confer superior antitumor immunity compared with effector memory T cells. Proc. Natl. Acad. Sci. USA 2005, 102, 9571-9576. [CrossRef]

18. Gattinoni, L.; Klebanoff, C.A.; Palmer, D.C.; Wrzesinski, C.; Kerstann, K.; Yu, Z.; Finkelstein, S.E.; Theoret, M.R.; Rosenberg, S.A.; Restifo, N.P. Acquisition of full effector function in vitro paradoxically impairs the in vivo antitumor efficacy of adoptively transferred CD8+ T cells. J. Clin. Investig. 2005, 115, 1616-1626. [CrossRef]

19. Yee, C.; Thompson, J.A.; Byrd, D.; Riddell, S.R.; Roche, P.; Celis, E.; Greenberg, P.D. Adoptive T cell therapy using antigen-specific CD8+ T cell clones for the treatment of patients with metastatic melanoma: In vivo persistence, migration, and antitumor effect of transferred T cells. Proc. Natl. Acad. Sci. USA 2002, 99, 16168-16173. [CrossRef]

20. Rosenberg, S.A.; Restifo, N.P.; Yang, J.C.; Morgan, R.A.; Dudley, M.E. Adoptive cell transfer: A clinical path to effective cancer immunotherapy. Nat. Rev. Cancer 2008, 8, 299-308. [CrossRef]

21. Dudley, M.E.; Wunderlich, J.R.; Yang, J.C.; Hwu, P.; Schwartzentruber, U.J.; Topalian, S.L.; Sherry, R.M.; Marincola, F.M.; Leitman, S.F.; Seipp, C.A.; et al. A phase I study of nonmyeloablative chemotherapy and adoptive transfer of autologous tumor antigen-specific $\mathrm{T}$ lymphocytes in patients with metastatic melanoma. J. Immunother. 2002, 25, 243-251. [CrossRef] [PubMed]

22. Alatrash, G.; Jakher, H.; Stafford, P.D.; Mittendorf, E.A. Cancer immunotherapies, their safety and toxicity. Expert Opin. Drug Saf. 2013, 12, 631-645. [CrossRef] [PubMed]

23. Restifo, N.P.; Dudley, M.E.; Rosenberg, S.A. Adoptive immunotherapy for cancer: Harnessing the T cell response. Nat. Rev. Immunol. 2012, 12, 269-281. [CrossRef] [PubMed]

24. Goodman, A.M.; Kato, S.; Bazhenova, L.; Patel, S.P.; Frampton, G.M.; Miller, V.; Stephens, P.J.; Daniels, G.A.; Kurzrock, R. Tumor mutational burden as an independent predictor of response to immunotherapy in diverse cancers. Mol. Cancer Ther. 2017, 16, 2598-2608. [CrossRef]

25. Yarchoan, M.; Hopkins, A.; Jaffee, E.M. Tumor mutational burden and response rate to PD-1 Inhibition. N. Engl. J. Med. 2017, 377, 2500-2501. [CrossRef] [PubMed]

26. Kmiecik, J.; Poli, A.; Brons, N.H.; Waha, A.; Eide, G.E.; Enger, P.; Øyvind; Zimmer, J.; Chekenya, M. Elevated $\mathrm{CD} 3+$ and CD8+ tumor-infiltrating immune cells correlate with prolonged survival in glioblastoma patients despite integrated immunosuppressive mechanisms in the tumor microenvironment and at the systemic level. J. Neuroimmunol. 2013, 264, 71-83. [CrossRef]

27. Kim, S.T.; Jeong, H.; Woo, O.H.; Seo, J.H.; Kim, A.; Lee, E.S.; Shin, S.W.; Kim, Y.H.; Kim, J.S.; Park, K. Tumor-infiltrating Lymphocytes, Tumor characteristics, and recurrence in patients with early breast cancer. Am. J. Clin. Oncol. 2013, 36, 224-231. [CrossRef]

28. Piersma, S.J.; Jordanova, E.S.; Van Poelgeest, M.; Kwappenberg, K.M.; Van Der Hulst, J.M.; Drijfhout, J.W.; Melief, C.J.; Kenter, G.G.; Fleuren, G.J.; Offringa, R.; et al. High number of intraepithelial CD8+Tumor-infiltrating lymphocytes is associated with the absence of lymph node metastases in patients with large early-stage cervical cancer. Cancer Res. 2007, 67, 354-361. [CrossRef]

29. Galon, J.; Costes, A.; Kirilovsky, A.; Mlecnik, B.; Lagorce-Pagès, C.; Tosolini, M.; Camus, M.; Zinzindohoué, F.; Bruneval, P.; Cugnenc, P.-H.; et al. Type, density, and location of immune cells within human colorectal tumors predict clinical outcome. Science 2006, 313, 1960-1964. [CrossRef]

30. Bernhard, H.; Neudorfer, J.; Gebhard, K.; Conrad, H.; Hermann, C.; Nährig, J.; Fend, F.; Weber, W.; Busch, D.H.; Peschel, C. Adoptive transfer of autologous, HER2-specific, cytotoxic T lymphocytes for the treatment of HER2-overexpressing breast cancer. Cancer Immunol. Immunother. 2007, 57, 271-280. [CrossRef]

31. Pockaj, B.A.; Sherry, R.M.; Wei, J.P.; Yannelli, J.R.; Carter, C.S.; Leitman, S.F.; Carasquillo, J.A.; Steinberg, S.M.; Rosenberg, S.A.; Yang, J.C. Localization of 111indium-labeled tumor infiltrating lymphocytes to tumor in patients receiving adoptive immunotherapy. Augmentation with cyclophosphamide and correlation with response. Cancer 1994, 73, 1731-1737. [CrossRef] 
32. John, L.B.; Kershaw, M.H.; Darcy, P. Blockade of PD-1 immunosuppression boosts CAR T-cell therapy. OncoImmunology 2013, 2, e26286. [CrossRef] [PubMed]

33. Hong, M.; Huang, C.; Loumagne, L.; Tow, C.; Mackay, C.R.; Kato, M.; Nardin, A.; Puaux, A.-L.; Prévost-Blondel, A.; Avril, M.-F.; et al. Chemotherapy Induces intratumoral Expression of Chemokines in cutaneous melanoma, favoring T-cell infiltration and tumor control. Cancer Res. 2011, 71, 6997-7009. [CrossRef] [PubMed]

34. Palmer, D.C.; Balasubramaniam, S.; Hanada, K.-I.; Wrzesinski, C.; Yu, Z.; Farid, S.; Theoret, M.R.; Hwang, L.N.; Klebanoff, C.A.; Gattinoni, L.; et al. Vaccine-stimulated, adoptively transferred CD8+ $\mathrm{T}$ cells traffic indiscriminately and ubiquitously while mediating specific tumor destruction1. J. Immunol. 2004, 173, 7209-7216. [CrossRef] [PubMed]

35. Masopust, D.; Schenkel, J.M. The integration of T cell migration, differentiation and function. Nat. Rev. Immunol. 2013, 13, 309-320. [CrossRef] [PubMed]

36. Nolz, J.C.; Starbeck-Miller, G.; Harty, J.T. Naive, effector and memory CD8 T-cell trafficking: Parallels and distinctions. Immunotherapy 2011, 3, 1223-1233. [CrossRef] [PubMed]

37. Mulligan, A.M.; Raitman, I.; Feeley, L.; Pinnaduwage, D.; Nguyen, L.T.; O'Malley, F.P.; Ohashi, P.S.; Andrulis, I.L. Tumoral lymphocytic infiltration and expression of the chemokine CXCL10 in breast cancers from the ontario familial breast cancer registry. Clin. Cancer Res. 2012, 19, 336-346. [CrossRef]

38. Harlin, H.; Meng, Y.; Peterson, A.C.; Zha, Y.; Tretiakova, M.; Slingluff, C.; McKee, M.; Gajewski, T.F. Chemokine expression in melanoma metastases associated with CD8+ T-cell recruitment. Cancer Res. 2009, 69, 3077-3085. [CrossRef]

39. Matsumura, S.; Wang, B.; Kawashima, N.; Braunstein, S.; Badura, M.; Cameron, T.O.; Babb, J.S.; Schneider, R.J.; Formenti, S.C.; Dustin, M.L.; et al. Radiation-induced CXCL16 release by breast cancer cells attracts effector T cells. J. Immunol. 2008, 181, 3099-3107. [CrossRef]

40. 4Musha, H.; Ohtani, H.; Mizoi, T.; Kinouchi, M.; Nakayama, T.; Shiiba, K.; Miyagawa, K.; Nagura, H.; Yoshie, O.; Sasaki, I. Selective infiltration of CCR5+CXCR3+ T lymphocytes in human colorectal carcinoma. Int. J. Cancer 2005, 116, 949-956. [CrossRef]

41. Bellone, M.; Calcinotto, A. Ways to enhance lymphocyte trafficking into tumors and fitness of tumor infiltrating lymphocytes. Front. Oncol. 2013, 3, 231. [CrossRef] [PubMed]

42. Buckanovich, R.J.; Facciabene, A.; Kim, S.; Benencia, F.; Sasaroli, D.; Balint, K.; Katsaros, D.; O’Brien-Jenkins, A.; Gimotty, P.A.; Coukos, G. Endothelin B receptor mediates the endothelial barrier to T cell homing to tumors and disables immune therapy. Nat. Med. 2008, 14, 28-36. [CrossRef] [PubMed]

43. Kershaw, M.H.; Wang, G.; Westwood, J.A.; Pachynski, R.K.; Tiffany, H.L.; Marincola, F.M.; Wang, E.; Young, H.A.; Murphy, P.M.; Hwu, P. Redirecting migration of T cells to Chemokine secreted from tumors by genetic modification with CXCR2. Hum. Gene Ther. 2002, 13, 1971-1980. [CrossRef] [PubMed]

44. Di Stasi, A.; De Angelis, B.; Rooney, C.M.; Zhang, L.; Mahendravada, A.; Foster, A.E.; Heslop, H.E.; Brenner, M.K.; Dotti, G.; Savoldo, B. T lymphocytes coexpressing CCR4 and a chimeric antigen receptor targeting CD30 have improved homing and antitumor activity in a Hodgkin tumor model. Blood 2009, 113, 6392-6402. [CrossRef] [PubMed]

45. Shrimali, R.K.; Yu, Z.; Theoret, M.R.; Chinnasamy, D.; Restifo, N.P.; Rosenberg, S.A. Antiangiogenic agents can increase lymphocyte infiltration into tumor and enhance the effectiveness of adoptive immunotherapy of cancer. Cancer Res. 2010, 70, 6171-6180. [CrossRef]

46. Jain, R.K. Normalization of tumor vasculature: An emerging concept in antiangiogenic therapy. Science 2005, 307, 58-62. [CrossRef]

47. Ganss, R.; Ryschich, E.; Klar, E.; Arnold, B.; Hämmerling, G.J. Combination of T-cell therapy and trigger of inflammation induces remodeling of the vasculature and tumor eradication. Cancer Res. 2002, 62, 1462-1470.

48. Johansson, A.; Hamzah, J.; Payne, C.J.; Ganss, R. Tumor-targeted TNF stabilizes tumor vessels and enhances active immunotherapy. Proc. Natl. Acad. Sci. USA 2012, 109, 7841-7846. [CrossRef]

49. Fu, X.; Rivera, A.; Tao, L.; Zhang, X. Genetically modified T cells targeting neovasculature efficiently destroy tumor blood vessels, shrink established solid tumors and increase nanoparticle delivery. Int. J. Cancer 2013, 133, 2483-2492. [CrossRef]

50. Chinnasamy, D.; Yu, Z.; Kerkar, S.P.; Zhang, L.; Morgan, R.A.; Restifo, N.P.; Rosenberg, S.A. Local delivery of lnterleukin-12 using $\mathrm{T}$ cells targeting VEGF receptor-2 eradicates multiple vascularized tumors in mice. Clin. Cancer Res. 2012, 18, 1672-1683. [CrossRef] 
51. Emerich, D.F.; Thanos, C.G. Nanotechnology and medicine. Expert Opin. Biol. Ther. 2003, 3, 655-663. [CrossRef]

52. Arruebo, M.; Pacheco, R.; Ibarra, M.R.; Santamaría, J. Magnetic nanoparticles for drug delivery applications. Nano Today 2007, 2, 22-32. [CrossRef]

53. Shenoy, D.; Little, S.R.; Langer, R.; Amiji, M. Poly(ethylene oxide)-modified poly(beta-amino ester) nanoparticles as a $\mathrm{pH}$-sensitive system for tumor-targeted delivery of hydrophobic drugs: Part 2. In vivo distribution and tumor localization studies. Pharm. Res. 2005, 22, 2107-2114. [CrossRef] [PubMed]

54. Cao, Y.; Gu, Y.; Ma, H.; Bai, J.; Liu, L.; Zhao, P.; He, H. Self-assembled nanoparticle drug delivery systems from galactosylated polysaccharide-doxorubicin conjugate loaded doxorubicin. Int. J. Biol. Macromol. 2010, 46, 245-249. [CrossRef]

55. McCarthy, D.P.; Hunter, Z.N.; Chackerian, B.; Shea, L.D.; Miller, S.D. Targeted immunomodulation using antigen-conjugated nanoparticles. Wiley Interdiscip. Rev. Nanomed. Nanobiotechnol. 2014, 6, 298-315. [CrossRef] [PubMed]

56. Mejías, R.; Pérez-Yagüe, S.; Gutierrez, L.; Cabrera, L.I.; Spada, R.; Acedo, P.; Serna, C.; Lázaro, F.J.; Villanueva, A.; Morales, M.P.; et al. Dimercaptosuccinic acid-coated magnetite nanoparticles for magnetically guided in vivo delivery of interferon gamma for cancer immunotherapy. Biomaterials 2011, 32, 2938-2952. [CrossRef] [PubMed]

57. Tartaj, P. Probing Nanomagnets' Interactions inside colloidal superparamagnetic composites: Aerosol versus surface template methods. ChemPhysChem 2003, 4, 1371-1375. [CrossRef]

58. Freeman, M.W.; Arrott, A.; Watson, J.H.L. Magnetism in Medicine. J. Appl. Phys. 1960, 31, 404-405. [CrossRef]

59. Okon, E.; Pouliquen, D.; Okon, P.; Kovaleva, Z.V.; Stepanova, T.P.; Lavit, S.G.; Kudryavtsev, B.N.; Jallet, P. Biodegradation of magnetite dextran nanoparticles in the rat. A histologic and biophysical study. Lab. Investig. 1994, 71, 895-903.

60. Gutierrez, L.; Lázaro, F.J.; Abadía, A.R.; Romero, M.S.; Quintana, C.; Morales, M.P.; Patiño, C.; Arranz, R. Bioinorganic transformations of liver iron deposits observed by tissue magnetic characterisation in a rat model. J. Inorg. Biochem. 2006, 100, 1790-1799. [CrossRef]

61. Rojas, J.M.; Gavilán, H.; Del Dedo, V.; Lorente-Sorolla, E.; Sanz-Ortega, L.; Da Silva, G.B.; Costo, R.; Perez-Yagüe, S.; Talelli, M.; Marciello, M.; et al. Time-course assessment of the aggregation and metabolization of magnetic nanoparticles. Acta Biomater. 2017, 58, 181-195. [CrossRef] [PubMed]

62. Zhu, N.; Ji, H.; Yu, P.; Niu, J.; Farooq, M.; Akram, M.; Udego, I.O.; Li, H.; Niu, X. Surface modification of magnetic iron oxide nanoparticles. Nanomaterials 2018, 8, 810. [CrossRef] [PubMed]

63. Biehl, P.; von der Lühe, M.; Dutz, S.; Schacher, F.H. Synthesis, characterization, and applications of magnetic nanoparticles featuring polyzwitterionic coatings. Polymers 2018, 10, 91. [CrossRef] [PubMed]

64. Gul, S.; Khan, S.B.; Rehman, I.U.; Khan, M.A.; Khan, M.I. A Comprehensive review of magnetic nanomaterials modern day theranostics. Front. Mater. 2019, 6. [CrossRef]

65. Stephan, M.T.; Moon, J.J.; Um, S.H.; Bershteyn, A.; Irvine, D.J. Therapeutic cell engineering with surface-conjugated synthetic nanoparticles. Nat. Med. 2010, 16, 1035-1041. [CrossRef] [PubMed]

66. Stephan, M.T.; Stephan, S.B.; Bak, P.; Chen, J.; Irvine, D.J. Synapse-directed delivery of immunomodulators using T-cell-conjugated nanoparticles. Biomaterials 2012, 33, 5776-5787. [CrossRef]

67. Huang, B.; Abraham, W.D.; Zheng, Y.; López, S.C.B.; Luo, S.S.; Irvine, D.J. Active targeting of chemotherapy to disseminated tumors using nanoparticle-carrying T cells. Sci. Transl. Med. 2015, 7, 291ra94. [CrossRef]

68. Wendel, M.; Galani, I.E.; Suri-Payer, E.; Cerwenka, A. Natural killer cell accumulation in tumors is dependent on IFN-gamma and CXCR3 ligands. Cancer Res. 2008, 68, 8437-8445. [CrossRef]

69. Jin, H.; Qian, Y.; Dai, Y.; Qiao, S.; Huang, C.; Lu, L.; Luo, Q.; Chen, J.; Zhang, Z. magnetic enrichment of dendritic cell vaccine in lymph node with fluorescent-magnetic nanoparticles enhanced cancer immunotherapy. Theranostics 2016, 6, 2000-2014. [CrossRef]

70. Tukmachev, D.; Lunov, O.; Zablotskii, V.; Dejneka, A.; Babič, M.; Syková, E.; Kubinová, Š. An effective strategy of magnetic stem cell delivery for spinal cord injury therapy. Nanoscale 2015, 7, 3954-3958. [CrossRef]

71. Mou, Y.; Su, H.; An, Y.; Han, W.; Huang, X.; Xia, G.; Ni, Y.; Zhang, Y.; Ma, J.; Hu, Q. The migration of synthetic magnetic nanoparticle labeled dendritic cells into lymph nodes with optical imaging. Int. J. Nanomed. 2013, 8, 3737-3744. [CrossRef] 
72. De Chickera, S.N.; Snir, J.; Willert, C.; Rohani, R.; Foley, R.; Foster, P.J.; Dekaban, G.A. Labelling dendritic cells with SPIO has implications for their subsequent in vivo migration as assessed with cellular MRI. Contrast Media Mol. Imaging 2011, 6, 314-327. [CrossRef]

73. Polyak, B.; Fishbein, I.; Chorny, M.; Alferiev, I.; Williams, D.; Yellen, B.; Friedman, G.; Levy, R.J. High field gradient targeting of magnetic nanoparticle-loaded endothelial cells to the surfaces of steel stents. Proc. Natl. Acad. Sci. USA 2008, 105, 698-703. [CrossRef]

74. Chertok, B.; David, A.E.; Huang, Y.; Yang, V.C. Glioma selectivity of magnetically targeted nanoparticles: A role of abnormal tumor hydrodynamics. J. Control. Release 2007, 122, 315-323. [CrossRef] [PubMed]

75. Jang, E.-S.; Shin, J.-H.; Ren, G.; Park, M.-J.; Cheng, K.; Chen, X.; Wu, J.C.; Sunwoo, J.B.; Cheng, Z. The manipulation of natural killer cells to target tumor sites using magnetic nanoparticles. Biomaterials 2012, 33, 5584-9552. [CrossRef] [PubMed]

76. Clemente-Casares, X.; Santamaria, P. Nanomedicine in autoimmunity. Immunol. Lett. 2014, 158, $167-174$. [CrossRef] [PubMed]

77. Sanz-Ortega, L.; Portilla, Y.; Pérez-Yagüe, S.; Barber, D.F. Magnetic targeting of adoptively transferred tumour-specific nanoparticle-loaded CD8+ T cells does not improve their tumour infiltration in a mouse model of cancer but promotes the retention of these cells in tumour-draining lymph nodes. J. Nanobiotechnol. 2019, 17, 1-24. [CrossRef] [PubMed]

78. Sanz-Ortega, L.; Rojas, J.M.; Marcos, A.; Portilla, Y.; Stein, J.V.; Barber, D.F. T cells loaded with magnetic nanoparticles are retained in peripheral lymph nodes by the application of a magnetic field. J. Nanobiotechnol. 2019, 17, 14. [CrossRef]

79. Sanz-Ortega, L.; Rojas, J.M.; Portilla, Y.; Pérez-Yagüe, S.; Barber, D.F. Magnetic nanoparticles attached to the NK cell surface for tumor targeting in adoptive transfer therapies does not affect cellular effector functions. Front. Immunol. 2019, 10, 10. [CrossRef]

80. Mühlberger, M.; Janko, C.; Unterweger, H.; Friedrich, R.P.; Friedrich, B.; Band, J.; Cebulla, N.; Alexiou, C.; Dudziak, D.; Lee, G.; et al. Functionalization of T Lymphocytes with citrate-coated superparamagnetic iron oxide nanoparticles for magnetically controlled immune therapy. Int. J. Nanomed. 2019, 14, 8421-8432. [CrossRef]

81. Mühlberger, M.; Unterweger, H.; Band, J.; Lehmann, C.H.K.; Heger, L.; Dudziak, D.; Alexiou, C.; Lee, G.; Janko, C. Loading of primary human T Lymphocytes with citrate-coated superparamagnetic iron oxide nanoparticles does not impair their activation after polyclonal stimulation. Cells 2020, 9, 342. [CrossRef]

82. Safi, R.; Shokrollahi, H. Physics, chemistry and synthesis methods of nanostructured bismuth ferrite (BiFeO3) as a ferroelectro-magnetic material. Prog. Solid State Chem. 2012, 40, 6-15. [CrossRef]

83. Patil, R.M.; Thorat, N.D.; Shete, P.B.; Bedge, P.A.; Gavde, S.; Joshi, M.G.; Tofail, S.A.; Bohara, R.A. Comprehensive cytotoxicity studies of superparamagnetic iron oxide nanoparticles. Biochem. Biophys. Rep. 2018, 13, 63-72. [CrossRef] [PubMed]

84. Singh, N.; Jenkins, G.J.S.; Asadi, R.; Doak, S.H. Potential toxicity of superparamagnetic iron oxide nanoparticles (SPION). Nano Rev. 2010, 1. [CrossRef] [PubMed]

85. Pisanic, T.R.; Blackwell, J.D.; Shubayev, V.I.; Finõnes, R.R.; Jin, S. Nanotoxicity of iron oxide nanoparticle internalization in growing neurons. Biomaterials 2007, 28, 2572-2581. [CrossRef]

86. Xu, Y.; Sherwood, J.A.; Lackey, K.H.; Qin, Y.; Bao, Y. The responses of immune cells to iron oxide nanoparticles. J. Appl. Toxicol. 2016, 36, 543-553. [CrossRef]

87. Gaharwar, U.S.; Meena, R.; Rajamani, P. Iron oxide nanoparticles induced cytotoxicity, oxidative stress and DNA damage in lymphocytes. J. Appl. Toxicol. 2017, 37, 1232-1244. [CrossRef]

88. Zupke, O.; Distler, E.; Jürchott, A.; Paiphansiri, U.; Dass, M.; Thomas, S.; Hartwig, U.F.; Theobald, M.; Landfester, K.; Mailänder, V.; et al. Nanoparticles and antigen-specific T-cell therapeutics: A comprehensive study on uptake and release. Nanomedicine 2015, 10, 1063-1076. [CrossRef]

89. Shah, A.; Dobrovolskaia, M.A. Immunological effects of iron oxide nanoparticles and iron-based complex drug formulations: Therapeutic benefits, toxicity, mechanistic insights, and translational considerations. Nanomed. Nanotechnol. Biol. Med. 2018, 14, 977-990. [CrossRef]

90. Strehl, C.; Schellmann, S.; Maurizi, L.; Hofmann-Amtenbrink, M.; Häupl, T.; Hofmann, H.; Buttgereit, F.; Gaber, T. Effects of PVA-coated nanoparticles on human T helper cell activity. Toxicol. Lett. 2016, 245, 52-58. [CrossRef] 
91. Easo, S.L.; Mohanan, P.V. Toxicological evaluation of dextran stabilized iron oxide nanoparticles in human peripheral blood lymphocytes. Biointerphases 2016, 11, 04B302. [CrossRef]

92. Unterweger, H.; Dezsi, L.; Matuszak, J.; Janko, C.; Pöttler, M.; Jordan, J.; Bäuerle, T.; Szebeni, J.; Fey, T.; Boccaccini, A.R.; et al. Dextran-coated superparamagnetic iron oxide nanoparticles for magnetic resonance imaging: Evaluation of size-dependent imaging properties, storage stability and safety. Int. J. Nanomed. 2018, 13, 1899-1915. [CrossRef] [PubMed]

93. Elias, A.; Tsourkas, A. Imaging circulating cells and lymphoid tissues with iron oxide nanoparticles. Hematol. Am. Soc. Hematol. Educ. Program 2009, 2009, 720-726. [CrossRef] [PubMed]

94. Smirnov, P.; Lavergne, E.; Gazeau, F.; Lewin, M.; Boissonnas, A.; Doan, B.-T.; Gillet, B.; Combadière, C.; Combadière, B.; Clément, $\mathrm{O}$. In vivo cellular imaging of lymphocyte trafficking by MRI: A tumor model approach to cell-based anticancer therapy. Magn. Reson. Med. 2006, 56, 498-508. [CrossRef] [PubMed]

95. Anderson, S.A.; Shukaliak-Quandt, J.; Jordan, E.K.; Arbab, A.S.; Martin, R.; McFarland, H.; Frank, J.A. Magnetic resonance imaging of labeled T-cells in a mouse model of multiple sclerosis. Ann. Neurol. 2004, 55, 654-659. [CrossRef]

96. Dodd, C.H.; Hsu, H.-C.; Chu, W.-J.; Yang, P.; Zhang, H.-G.; Zinn, K.R.; Forder, J.; Josephson, L.; Weissleder, R.; Mountz, J.M.; et al. Normal T-cell response and in vivo magnetic resonance imaging of $\mathrm{T}$ cells loaded with HIV transactivator-peptide-derived superparamagnetic nanoparticles. J. Immunol. Methods 2001, 256, 89-105. [CrossRef]

97. Mallett, C.L.; McFadden, C.; Chen, Y.; Foster, P.J. Migration of iron-labeled KHYG-1 natural killer cells to subcutaneous tumors in nude mice, as detected by magnetic resonance imaging. Cytotherapy 2012, 14, 743-751. [CrossRef]

98. Meier, R.; Golovko, D.; Tavri, S.; Henning, T.D.; Knopp, C.; Piontek, G.; Rudelius, M.; Heinrich, P.; Wels, W.S.; Daldrup-Link, H.E. Depicting adoptive immunotherapy for prostate cancer in an animal model with magnetic resonance imaging. Magn. Reson. Med. 2010, 65, 756-763. [CrossRef]

99. Daldrup-Link, H.E.; Meier, R.; Rudelius, M.; Piontek, G.; Piert, M.; Metz, S.; Settles, M.; Uherek, C.; Wels, W.; Schlegel, J.; et al. In vivo tracking of genetically engineered, anti-HER2/neu directed natural killer cells to HER2/neu positive mammary tumors with magnetic resonance imaging. Eur. Radiol. 2005, 15, 4-13. [CrossRef]

100. Chao, T.; Wang, H.; Ho, P.-C. Mitochondrial control and guidance of cellular activities of T cells. Front. Immunol. 2017, 8, 473. [CrossRef]

101. Gardiner, C.M.; Finlay, D.K. What Fuels Natural Killers? Metabolism and NK cell responses. Front. Immunol. 2017, 8, 367. [CrossRef] [PubMed]

102. Baixauli, F.; Martín-Cófreces, N.B.; Morlino, G.; Carrasco, Y.R.; Calabia-Linares, C.; Veiga, E.; Serrador, J.M.; Sánchez-Madrid, F. The mitochondrial fission factor dynamin-related protein 1 modulates T-cell receptor signalling at the immune synapse. EMBO J. 2011, 30, 1238-1250. [CrossRef] [PubMed]

103. Sena, L.A.; Li, S.; Jairaman, A.; Prakriya, M.; Ezponda, T.; Hildeman, D.A.; Wang, C.-R.; Schumacker, P.T.; Licht, J.D.; Perlman, H.; et al. Mitochondria are required for antigen-specific T cell activation through reactive oxygen species signaling. Immunity 2013, 38, 225-236. [CrossRef] [PubMed]

104. Huang, G.; Chen, H.; Dong, Y.; Luo, X.; Yu, H.; Moore, Z.; Bey, E.A.; Boothman, D.A.; Gao, J. superparamagnetic iron oxide nanoparticles: Amplifying ROS stress to improve anticancer drug efficacy. Theranostics 2013, 3, 116-126. [CrossRef] [PubMed]

105. Voinov, M.A.; Pagán, J.O.S.; Morrison, E.; Smirnova, T.I.; Smirnov, A.I. Surface-mediated production of Hydroxyl radicals as a mechanism of iron oxide nanoparticle biotoxicity. J. Am. Chem. Soc. 2011, 133, 35-41. [CrossRef] [PubMed]

106. Buck, M.D.; O’Sullivan, D.; Pearce, E.L. T cell metabolism drives immunity. J. Cell Biol. 2015, $210,2104$. [CrossRef]

107. Imanishi, T.; Saito, T. T Cell Co-stimulation and Functional Modulation by Innate Signals. Trends Immunol. 2020, 41, 200-212. [CrossRef]

108. Mulén, B.; Rojas, J.M.; Pérez-Yagüe, S.; Morales, M.P.; Barber, D.F. Polyethylenimine-coated SPION exhibits potential intrinsic anti-metastatic properties inhibiting migration and invasion of pancreatic tumor cells. J. Control. Release 2015, 216, 78-92. [CrossRef] 
109. Ottersbach, A.; Mykhaylyk, O.; Heidsieck, A.; Eberbeck, D.; Rieck, S.; Zimmermann, K.; Breitbach, M.; Engelbrecht, B.; Brügmann, T.; Hesse, M.; et al. Improved heart repair upon myocardial infarction: Combination of magnetic nanoparticles and tailored magnets strongly increases engraftment of myocytes. Biomaterials 2018, 155, 176-190. [CrossRef]

110. Zupke, O.; Distler, E.; Baumann, D.; Strand, D.; Meyer, R.; Landfester, K.; Herr, W.; Mailänder, V. Preservation of dendritic cell function upon labeling with amino functionalized polymeric nanoparticles. Biomaterials 2010, 31, 7086-7095. [CrossRef]

111. Pai, A.; Cao, P.; White, E.E.; Hong, B.; Pailevanian, T.; Wang, M.; Badie, B.; Hajimiri, A.; Berlin, J.M. Dynamically programmable magnetic fields for controlled movement of cells loaded with iron oxide nanoparticles. ACS Appl. Bio Mater. 2020, 3, 4139-4147. [CrossRef]

112. Berger, C.; Rausch, M.; Schmidt, P.; Rudin, M. Feasibility and limits of magnetically labeling primary cultured rat $\mathrm{T}$ cells with ferumoxides coupled with commonly used transfection agents. Mol. Imaging 2006, 5, 93-104. [CrossRef] [PubMed]

113. Lunov, O.; Syrovets, T.; Loos, C.; Beil, J.; Delacher, M.; Tron, K.; Nienhaus, G.U.; Musyanovych, A.; Mailänder, V.; Landfester, K.; et al. Differential uptake of functionalized polystyrene nanoparticles by human macrophages and a monocytic cell line. ACS Nano 2011, 5, 1657-1669. [CrossRef] [PubMed]

114. He, C.; Hu, Y.; Yin, L.; Tang, C.; Yin, C. Effects of particle size and surface charge on cellular uptake and biodistribution of polymeric nanoparticles. Biomaterials 2010, 31, 3657-3666. [CrossRef] [PubMed]

115. Waiczies, S.; Niendorf, T.; Lombardi, G. Labeling of cell therapies: How can we get it right? OncoImmunology 2017, 6, e1345403. [CrossRef] [PubMed]

116. Lankoff, A.; Arabski, M.; Wegierek-Ciuk, A.; Kruszewski, M.; Lisowska, H.; Banasik-Nowak, A.; Rózga-Wijas, K.; Wojewódzka, M.; Slomkowski, S. Effect of surface modification of silica nanoparticles on toxicity and cellular uptake by human peripheral blood lymphocytes in vitro. Nanotoxicology 2012, 7, 235-250. [CrossRef]

117. Smirnov, P. Cellular magnetic resonance imaging using superparamagnetic anionic iron oxide nanoparticles: Applications to in vivo trafficking of lymphocytes and cell-based anticancer therapy. Methods Mol. Biol. 2009, 512, 333-353. [CrossRef]

118. Garden, O.; Reynolds, P.; Yates, J.; Larkman, D.; Marelli-Berg, F.; Haskard, D.; Edwards, A.; George, A.J. A rapid method for labelling CD4+ T cells with ultrasmall paramagnetic iron oxide nanoparticles for magnetic resonance imaging that preserves proliferative, regulatory and migratory behaviour in vitro. J. Immunol. Methods 2006, 314, 123-133. [CrossRef]

119. Chen, C.-L.; Siow, T.Y.; Chou, C.-H.; Lin, C.-H.; Lin, M.-H.; Chen, Y.-C.; Hsieh, W.-Y.; Wang, S.-J.; Chang, C. Targeted superparamagnetic iron oxide nanoparticles for in vivo magnetic resonance imaging of $\mathrm{t}$-cells in rheumatoid arthritis. Mol. Imaging Biol. 2016, 19, 233-244. [CrossRef]

120. Rivolta, I.; Panariti, A.; Miserocchi, G. The effect of nanoparticle uptake on cellular behavior: Disrupting or enabling functions? Nanotechnol. Sci. Appl. 2012, 5, 87-100. [CrossRef]

121. Kralj, S.; Rojnik, M.; Romih, R.; Jagodič, M.; Kos, J.; Makovec, D. Effect of surface charge on the cellular uptake of fluorescent magnetic nanoparticles. J. Nanoparticle Res. 2012, 14, 1-14. [CrossRef]

122. Yue, Z.-G.; Wei, W.; Lv, P.-P.; Yue, H.; Wang, L.-Y.; Su, Z.-G.; Ma, G.-H. Surface charge affects cellular uptake and intracellular trafficking of chitosan-based nanoparticles. Biomacromolecules 2011, 12, 2440-2446. [CrossRef] [PubMed]

123. Zhao, F.; Zhao, Y.; Liu, Y.; Chang, X.-L.; Chen, C.; Zhao, Y. Cellular uptake, intracellular trafficking, and Cytotoxicity of nanomaterials. Small 2011, 7, 1322-1337. [CrossRef] [PubMed]

124. Verma, A.; Stellacci, F. Effect of surface properties on nanoparticle-cell interactions. Small 2010, 6, 12-21. [CrossRef] [PubMed]

125. Orr, G.; Panther, D.J.; Cassens, K.J.; Phillips, J.L.; Tarasevich, B.J.; Pounds, J.G. Syndecan-1 mediates the coupling of positively charged submicrometer amorphous silica particles with actin filaments across the alveolar epithelial cell membrane. Toxicol. Appl. Pharmacol. 2009, 236, 210-220. [CrossRef]

126. Patil, S.; Sandberg, A.; Heckert, E.; Self, W.T.; Seal, S. Protein adsorption and cellular uptake of cerium oxide nanoparticles as a function of zeta potential. Biomaterials 2007, 28, 4600-4607. [CrossRef]

127. Meng, Y.; Shi, C.; Hu, B.; Gong, J.; Zhong, X.; Lin, X.; Zhang, X.; Liu, J.; Liu, C.; Xu, H. External magnetic field promotes homing of magnetized stem cells following subcutaneous injection. BMC Cell Biol. 2017, 18, 24. [CrossRef] 
128. Liao, N.; Wu, M.; Pan, F.; Lin, J.; Li, Z.; Zhang, D.; Wang, Y.; Zheng, Y.; Peng, J.; Liu, X.; et al. Poly (dopamine) coated superparamagnetic iron oxide nanocluster for noninvasive labeling, tracking and targeted delivery of adipose tissue-derived stem cells. Sci. Rep. 2016, 6, 18746. [CrossRef]

129. Xu, Y.; Wu, C.; Zhu, W.; Xia, C.; Wang, D.; Zhang, H.; Wu, J.; Lin, G.; Wu, B.; Gong, Q.; et al. Superparamagnetic MRI probes for in vivo tracking of dendritic cell migration with a clinical $3 \mathrm{~T}$ scanner. Biomaterials 2015, 58, 63-71. [CrossRef]

130. Janic, B.; Rad, A.M.; Jordan, E.K.; Iskander, A.S.M.; Ali, M.; Varma, N.R.S.; Frank, J.A.; Arbab, A.S. Optimization and validation of FePro cell labeling method. PLoS ONE 2009, 4, e5873. [CrossRef]

131. Iida, H.; Takayanagi, K.; Nakanishi, T.; Kume, A.; Muramatsu, K.; Kiyohara, Y.; Akiyama, Y.; Osaka, T. Preparation of human immune effector T cells containing iron-oxide nanoparticles. Biotechnol. Bioeng. 2008, 101, 1123-1128. [CrossRef] [PubMed]

132. Kircher, M.F.; Allport, J.R.; Graves, E.E.; Love, V.; Josephson, L.; Lichtman, A.H.; Weissleder, R. In vivo high resolution three-dimensional imaging of antigen-specific cytotoxic T-lymphocyte trafficking to tumors. Cancer Res. 2003, 63, 6838-6846. [PubMed]

133. Yan, L.; Liu, X.; Liu, W.-X.; Tan, X.; Xiong, F.; Gu, N.; Hao, W.; Gao, X.; Cao, J. $\mathrm{Fe}_{2} \mathrm{O}_{3}$ nanoparticles suppress $\mathrm{Kv} 1.3$ channels via affecting the redox activity of $\mathrm{Kv} \beta 2$ subunit in Jurkat T cells. Nanotechnology 2015, 26, 505103. [CrossRef] [PubMed]

134. Alkins, R.; Burgess, A.; Ganguly, M.; Francia, G.; Kerbel, R.; Wels, W.S.; Hynynen, K. Focused ultrasound delivers targeted immune cells to metastatic brain tumors. Cancer Res. 2013, 73, 1892-1899. [CrossRef]

135. Galli, F.; Histed, S.; Aras, O. NK cell imaging by in vitro and in vivo labelling approaches. Q. J. Nucl. Med. Mol. Imaging 2014, 58, 276-283.

136. Long, E.O.; Kim, H.S.; Liu, N.; Peterson, M.E.; Rajagopalan, S. Controlling natural killer cell responses: Integration of signals for activation and inhibition. Annu. Rev. Immunol. 2013, 31, 227-258. [CrossRef]

137. Tay, C.Y.; Cai, P.; Setyawati, M.I.; Fang, W.; Tan, L.P.; Hong, C.H.L.; Chen, X.; Leong, D.T. Nanoparticles strengthen intracellular tension and retard cellular migration. Nano Lett. 2013, 14, 83-88. [CrossRef]

138. Diana, V.; Bossolasco, P.; Moscatelli, D.; Silani, V.; Covaa, L. Dose dependent side effect of superparamagnetic iron oxide nanoparticle labeling on cell motility in two fetal stem cell populations. PLoS ONE 2013, 8, e78435. [CrossRef]

139. Khaleghian, A.; Riazi, G.H.; Ghafari, M.; Rezaie, M.; Takahashi, A.; Nakaya, Y.; Nazari, H. Effect of inganen anticancer properties on microtobule organization. Pak. J. Pharm. Sci. 2010, 23, 273-278.

140. Soenen, S.J.H.; Nuytten, N.; De Meyer, S.F.; De Smedt, S.C.; De Cuyper, M. High intracellular iron oxide nanoparticle concentrations affect cellular cytoskeleton and focal adhesion kinase-mediated signaling. Small 2010, 6, 832-842. [CrossRef]

141. Alter, G.; Malenfant, J.; Altfeld, M. CD107a as a functional marker for the identification of natural killer cell activity. J. Immunol. Methods 2004, 294, 15-22. [CrossRef] [PubMed]

142. Wu, Y.; Tian, Z.; Wei, H. Developmental and functional control of natural killer cells by Cytokines. Front. Immunol. 2017, 8, 930. [CrossRef]

143. Cooper, M.A.; Fehniger, T.A.; Caligiuri, M.A. The biology of human natural killer-cell subsets. Trends Immunol. 2001, 22, 633-640. [CrossRef]

144. Warren, H.S.; Kinnear, B.F.; Phillips, J.H.; Lanier, L.L. Production of IL-5 by human NK cells and regulation of IL-5 secretion by IL-4, IL-10, and IL-12. J. Immunol. 1995, 154, 5144-5152. [PubMed]

145. Roda, J.M. Natural killer cells produce T cell-recruiting Chemokines in response to antibody-coated tumor cells. Cancer Res. 2006, 66, 517-526. [CrossRef] [PubMed]

146. Fehniger, T.A.; Shah, M.H.; Turner, M.J.; VanDeusen, J.B.; Whitman, S.P.; Cooper, M.A.; Suzuki, K.; Wechser, M.; Goodsaid, F.; Caligiuri, M.A. Differential cytokine and chemokine gene expression by human NK cells following activation with IL-18 or IL-15 in combination with IL-12: Implications for the innate immune response. J. Immunol. 1999, 162, 4511-4520. [PubMed]

147. Fauriat, C.; Long, E.O.; Ljunggren, H.-G.; Bryceson, Y.T. Regulation of human NK-cell cytokine and chemokine production by target cell recognition. Blood 2010, 115, 2167-2176. [CrossRef]

148. Albuquerque, W.W.C.; Costa, R.M.P.B.; Fernandes, T.D.S.E.; Porto, A.L.F. Evidences of the static magnetic field influence on cellular systems. Prog. Biophys. Mol. Biol. 2016, 121, 16-28. [CrossRef]

149. Dini, L.; Abbro, L. Bioeffects of moderate-intensity static magnetic fields on cell cultures. Micron 2005, 36, 195-217. [CrossRef] 
150. Rosen, A.D. Mechanism of action of moderate-intensity static magnetic fields on biological systems. Cell Biophys. 2003, 39, 163-174. [CrossRef]

151. Joseph, N.; Reicher, B.; Barda-Saad, M. The calcium feedback loop and T cell activation: How cytoskeleton networks control intracellular calcium flux. Biochim. Et Biophys. Acta 2014, 1838, 557-568. [CrossRef] [PubMed]

152. Dixit, N.; Kim, M.-H.; Rossaint, J.; Yamayoshi, I.; Zarbock, A.; Simon, S.I. Leukocyte Function Antigen-1, Kindlin-3, and Calcium Flux Orchestrate Neutrophil Recruitment during Inflammation. J. Immunol. 2012, 189, 5954-5964. [CrossRef] [PubMed]

153. Macdonald, C.; Friedman, G.; Alamia, J.; Barbee, K.; Polyak, B. Time-varied magnetic field enhances transport of magnetic nanoparticles in viscous gel. Nanomedicine 2010, 5, 65-76. [CrossRef] [PubMed]

154. Kolosnjaj-Tabi, J.; Wilhelm, C.; Clément, O.; Gazeau, F. Cell labeling with magnetic nanoparticles: Opportunity for magnetic cell imaging and cell manipulation. J. Nanobiotechnol. 2013, 11, S7. [CrossRef] [PubMed]

155. Asperti-Boursin, F.; Real, E.; Bismuth, G.; Trautmann, A.; Donnadieu, E. CCR7 ligands control basal T cell motility within lymph node slices in a phosphoinositide 3-kinase- independent manner. J. Exp. Med. 2007, 204, 1167-1179. [CrossRef]

156. Wei, S.H.; Safrina, O.; Yu, Y.; Garrod, K.R.; Cahalan, M.D.; Parker, I. Ca2+ signals in CD4+ T cells during early contacts with antigen-bearing dendritic cells in lymph node. J. Immunol. 2007, 179, 1586-1594. [CrossRef]

157. Dixit, N.; Simon, S.I. Chemokines, selectins and intracellular calcium flux: Temporal and spatial cues for leukocyte arrest. Front. Immunol. 2012, 3, 188. [CrossRef]

158. Zablotskii, V.; Polyakova, T.; Lunov, O.; Dejneka, A. How a high-gradient magnetic field could affect cell life. Sci. Rep. 2016, 6, 37407. [CrossRef]

159. Kobukai, S.; Baheza, R.; Cobb, J.G.; Virostko, J.; Xie, J.; Gillman, A.; Koktysh, D.; Kerns, D.; Does, M.; Gore, J.C.; et al. Magnetic nanoparticles for imaging dendritic cells. Magn. Reson. Med. 2010, 63, 1383-1390. [CrossRef]

160. Goya, G.; Marcos-Campos, I.; Fernández-Pacheco, R.; Saez, B.; Godino, J.; Asin, L.; Lambea, J.; Tabuenca, P.; Mayordomo, J.; Larrad, L. Dendritic cell uptake of iron-based magnetic nanoparticles. Cell Biol. Int. 2008, 32, 1001-1005. [CrossRef]

161. Cho, N.-H.; Cheong, T.-C.; Min, J.H.; Wu, J.H.; Lee, S.J.; Kim, D.; Yang, J.-S.; Kim, S.; Kim, Y.K.; Seong, S.-Y. A multifunctional core-shell nanoparticle for dendritic cell-based cancer immunotherapy. Nat. Nanotechnol. 2011, 6, 675-682. [CrossRef] [PubMed]

162. Bedrosian, I.; Mick, R.; Xu, S.; Nisenbaum, H.; Faries, M.; Zhang, P.; Cohen, P.A.; Koski, G.; Czerniecki, B.J. Intranodal administration of peptide-pulsed mature dendritic cell vaccines results in superior CD8+ T-Cell function in melanoma patients. J. Clin. Oncol. 2003, 21, 3826-3835. [CrossRef] [PubMed]

163. Draube, A.; Klein-Gonzalez, N.; Mattheus, S.; Brillant, C.; Hellmich, M.; Engert, A.; Von Bergwelt-Baildon, M. Dendritic cell based tumor vaccination in prostate and renal cell cancer: A systematic review and meta-analysis. PLoS ONE 2011, 6, e18801. [CrossRef] [PubMed]

164. Samy, E.T.; Parker, L.A.; Sharp, C.P.; Tung, K.S. Continuous control of autoimmune disease by antigen-dependent polyclonal CD4+CD25+ regulatory T cells in the regional lymph node. J. Exp. Med. 2005, 202, 771-781. [CrossRef] [PubMed]

165. Ozga, A.J.; Moalli, F.; Abe, J.; Swoger, J.; Sharpe, J.; Zehn, D.; Kreutzfeldt, M.; Merkler, D.; Ripoll, J.; Stein, J.V. pMHC affinity controls duration of CD8+ T cell-DC interactions and imprints timing of effector differentiation versus expansion. J. Exp. Med. 2016, 213, 2811-2829. [CrossRef] [PubMed]

166. Schell, A.M.; Granger, E.L.; Koczot, F.; Fischer, M.A.; Norbury, C.C. Dendritic cell migration limits the duration of CD8+ T-cell priming to peripheral viral antigen. J. Virol. 2010, 84, 3586-3594. [CrossRef]

167. Celli, S.; Lemaitre, F.; Bousso, P. Real-time manipulation of T cell-dendritic cell interactions in vivo reveals the importance of prolonged contacts for CD4+ T cell activation. Immunity 2007, 27, 625-634. [CrossRef]

168. Sabado, R.L.; Bhardwaj, N. Directing dendritic cell immunotherapy towards successful cancer treatment. Immunotherapy 2010, 2, 37-56. [CrossRef]

169. Mandl, J.N.; Liou, R.; Klauschen, F.; Vrisekoop, N.; Monteiro, J.P.; Yates, A.J.; Huang, A.Y.; Germain, R.N. Quantification of lymph node transit times reveals differences in antigen surveillance strategies of naive CD4+ and CD8+ T cells. Proc. Natl. Acad. Sci. USA 2012, 109, 18036-18041. [CrossRef] 
170. Ménager, J.; Gorin, J.-B.; Maurel, C.; Drujont, L.; Gouard, S.; Louvet, C.; Chérel, M.; Faivre-Chauvet, A.; Morgenstern, A.; Bruchertseifer, F.; et al. Combining $\alpha$-radioimmunotherapy and Adoptive T cell therapy to potentiate tumor destruction. PLoS ONE 2015, 10, e0130249. [CrossRef]

171. Shrikant, P.; Mescher, M.F. Control of syngeneic tumor growth by activation of CD8+ T cells: Efficacy is limited by migration away from the site and induction of nonresponsiveness. J. Immunol. 1999, 162, 2858-2866.

172. Rotariu, O.; Strachan, N.J. Modelling magnetic carrier particle targeting in the tumor microvasculature for cancer treatment. J. Magn. Magn. Mater. 2005, 293, 639-646. [CrossRef]

173. Garris, C.S.; Blaho, V.A.; Hla, T.; Han, M.H. Sphingosine-1-phosphate receptor 1 signalling in T cells: Trafficking and beyond. Immunology 2014, 142, 347-353. [CrossRef] [PubMed]

174. Cyster, J.G.; Schwab, S.R. Sphingosine-1-Phosphate and Lymphocyte egress from lymphoid organs. Annu. Rev. Immunol. 2012, 30, 69-94. [CrossRef] [PubMed]

175. Schwab, S.R.; Pereira, J.P.; Matloubian, M.; Xu, Y.; Huang, Y.; Cyster, J.G. Lymphocyte Sequestration Through S1P Lyase Inhibition and Disruption of S1P Gradients. Science 2005, 309, 1735-1739. [CrossRef]

176. Brinkmann, V.; Lynch, K.R. FTY720: Targeting G-protein-coupled receptors for sphingosine 1-phosphate in transplantation and autoimmunity. Curr. Opin. Immunol. 2002, 14, 569-575. [CrossRef]

177. Benechet, A.P.; Menon, M.; Xu, D.; Samji, T.; Maher, L.; Murooka, T.T.; Mempel, T.R.; Sheridan, B.S.; Lemoine, F.M.; Khanna, K.M. T cell-intrinsic S1PR1 regulates endogenous effector T-cell egress dynamics from lymph nodes during infection. Proc. Natl. Acad. Sci. USA 2016, 113, 2182-2187. [CrossRef]

178. Bankovich, A.J.; Shiow, L.R.; Cyster, J.G. CD69 Suppresses Sphingosine 1-Phosophate Receptor-1 (S1P1) Function through Interaction with Membrane Helix 4. J. Biol. Chem. 2010, 285, 22328-22337. [CrossRef]

179. Shiow, L.R.; Rosen, D.B.; Brdičková, N.; Xu, Y.; An, J.; Lanier, L.L.; Cyster, J.G.; Matloubian, M. CD69 acts downstream of interferon-alpha/beta to inhibit S1P1 and lymphocyte egress from lymphoid organs. Nature 2006, 440, 540-544. [CrossRef]

180. Geng, S.; Zhong, Y.; Zhou, X.; Zhao, G.; Xie, X.; Pei, Y.; Liu, H.; Zhang, H.; Shi, Y.; Wang, B. Induced regulatory $\mathrm{T}$ cells superimpose their suppressive capacity with effector $\mathrm{T}$ cells in lymph nodes via antigen-specific S1p1-dependent egress blockage. Front. Immunol. 2017, 8, 663. [CrossRef]

181. Mueller, S.N.; Hosiawa-Meagher, K.A.; Konieczny, B.T.; Sullivan, B.M.; Bachmann, M.F.; Locksley, R.M.; Ahmed, R.; Matloubian, M. Regulation of homeostatic Chemokine expression and cell trafficking during immune responses. Science 2007, 317, 670-674. [CrossRef] [PubMed]

182. Dustin, M.L.; Bromley, S.K.; Kan, Z.; Peterson, D.A.; Unanue, E.R. Antigen receptor engagement delivers a stop signal to migrating T lymphocytes. Proc. Natl. Acad. Sci. USA 1997, 94, 3909-3913. [CrossRef] [PubMed]

183. Dustin, M.L. T-cell activation through immunological synapses and kinapses. Immunol. Rev. 2008, 221, 77-89. [CrossRef] [PubMed]

184. Cernuda-Morollón, E.; Millán, J.; Shipman, M.; Marelli-Berg, F.M.; Ridley, A.J. Rac Activation by the T-cell receptor inhibits T cell migration. PLoS ONE 2010, 5, e12393. [CrossRef]

185. Valitutti, S.; Coombs, D.; Dupré, L. The space and time frames of T cell activation at the immunological synapse. FEBS Lett. 2010, 584, 4851-4857. [CrossRef]

186. Del Pozo, M.A.; Sánchez-Mateos, P.; Nieto, M.; Sánchez-Madrid, F. Chemokines regulate cellular polarization and adhesion receptor redistribution during lymphocyte interaction with endothelium and extracellular matrix. Involvement of cAMP signaling pathway. J. Cell Biol. 1995, 131, 495-508. [CrossRef]

187. Audemard-Verger, A.; Rivière, M.; Durand, A.; Peranzoni, E.; Guichard, V.; Hamon, P.; Bonilla, N.; Guilbert, T.; Boissonnas, A.; Auffray, C.; et al. Macrophages induce long-term trapping of gammadelta T cells with innate-like properties within secondary lymphoid organs in the steady state. J. Immunol. 2017, 199, 1998-2007. [CrossRef]

188. Palecek, S.P.; Loftus, J.C.; Ginsberg, M.; Lauffenburger, D.A.; Horwitz, A.F. Integrin-ligand binding properties govern cell migration speed through cell-substratum adhesiveness. Nature 1997, 385, 537-540. [CrossRef]

189. Baeyens, A.; Fang, V.; Chen, C.; Schwab, S.R. Exit Strategies: S1P Signaling and T Cell Migration. Trends Immunol. 2015, 36, 778-787. [CrossRef]

190. Haig, D.M.; Hopkins, J.; Miller, H.R.P. Local immune responses in afferent and efferent lymph. Immunology 1999, 96, 155-163. [CrossRef]

191. Steinman, L. Immunology of relapse and remission in multiple sclerosis. Annu. Rev. Immunol. 2014, 32, 257-281. [CrossRef] [PubMed] 
192. Brinkmann, V.; Billich, A.; Baumruker, T.; Heining, P.; Schmouder, R.; Francis, G.; Aradhye, S.; Burtin, P. Fingolimod (FTY720): Discovery and development of an oral drug to treat multiple sclerosis. Nat. Rev. Drug Discov. 2010, 9, 883-897. [CrossRef]

193. Liu, H.; Dong, H.; Zhou, N.; Dong, S.; Chen, L.; Zhu, Y.; Hu,H.-m.; Mou, Y. SPIO enhance the cross-presentation and migration of DCs and anionic SPIO influence the nanoadjuvant effects Related to Interleukin-1beta. Nanoscale Res. Lett. 2018, 13, 409. [CrossRef] [PubMed]

194. Jin, R.; Liu, L.; Zhu, W.; Li, D.; Yang, L.; Duan, J.; Cai, Z.; Nie, Y.; Zhang, Y.; Gong, Q.; et al. Iron oxide nanoparticles promote macrophage autophagy and inflammatory response through activation of toll-like Receptor-4 signaling. Biomaterials 2019, 203, 23-30. [CrossRef] [PubMed]

195. Hickey, J.W.; Isser, A.Y.; Vicente, F.P.; Warner, S.; Mao, H.; Schneck, J.P. Efficient magnetic enrichment of antigen-specific T cells by engineering particle properties. Biomaterials 2018, 187, 105-116. [CrossRef]

196. Morgan, R.A.; Dudley, M.E.; Wunderlich, J.R.; Hughes, M.S.; Yang, J.C.; Sherry, R.M.; Royal, R.E.; Topalian, S.L.; Kammula, U.S.; Restifo, N.P.; et al. Cancer regression in patients after transfer of genetically engineered lymphocytes. Science 2006, 314, 126-129. [CrossRef]

197. Seliger, B. Different regulation of MHC Class I antigen processing components in human tumors. J. Immunotoxicol. 2008, 5, 361-367. [CrossRef]

198. Vonderheide, R.H.; June, C.H. Engineering T cells for cancer: Our synthetic future. Immunol. Rev. 2014, 257,7-13. [CrossRef]

199. Kalos, M. Muscle CARs and TcRs: Turbo-charged technologies for the (T cell) masses. Cancer Immunol. Immunother. 2011, 61, 127-135. [CrossRef]

200. Lipowska-Bhalla, G.; Gilham, D.E.; Hawkins, R.E.; Rothwell, D.G. Targeted immunotherapy of cancer with CAR T cells: Achievements and challenges. Cancer Immunol. Immunother. 2012, 61, 953-962. [CrossRef]

201. Ramos, C.A.; Dotti, G. Chimeric antigen receptor (CAR)-engineered lymphocytes for cancer therapy. Expert Opin. Biol. Ther. 2011, 11, 855-873. [CrossRef] [PubMed]

202. Kahlon, K.S.; Brown, C.; Cooper, L.J.N.; Raubitschek, A.; Forman, S.J.; Jensen, M.C.; Yin, N.; Wang, D.; Zhang, H.; Yi, X.; et al. Specific recognition and killing of glioblastoma multiforme by Interleukin 13-Zetakine redirected Cytolytic T cells. Cancer Res. 2004, 64, 9160-9166. [CrossRef] [PubMed]

203. Maude, S.L.; Shpall, E.J.; Grupp, S.A. Chimeric antigen receptor T-cell therapy for ALL. Hematology 2014, 2014, 559-564. [CrossRef] [PubMed]

204. Zhang, C.; Oberoi, P.; Oelsner, S.; Waldmann, A.; Lindner, A.; Tonn, T.; Wels, W.S. Chimeric antigen receptor-engineered NK-92 Cells: An Off-the-Shelf Cellular Therapeutic for Targeted Elimination of Cancer Cells and Induction of Protective Antitumor Immunity. Front. Immunol. 2017, 8, 533. [CrossRef]

205. Suck, G. Novel approaches using natural killer cells in cancer therapy. Semin. Cancer Biol. 2006, 16, 412-418. [CrossRef]

206. Nie, W.; Wei, W.; Zuo, L.; Lv, C.; Zhang, F.; Lu, G.-H.; Li, F.; Wu, G.; Huang, L.-L.; Xi, X.; et al. Magnetic nanoclusters armed with responsive PD-1 antibody synergistically improved adoptive T-cell therapy for solid tumors. ACS Nano 2019, 13, 1469-1478. [CrossRef]

207. Pellico, J.; Ruíz-Cabello, J.; Fernandez-Barahona, I.; Gutierrez, L.; Lechuga-Vieco, A.V.; Enriquez, J.A.; Morales, M.P.; Herranz, F. One-step fast synthesis of nanoparticles for MRI: Coating chemistry as the key variable determining positive or negative contrast. Langmuir 2017, 33, 10239-10247. [CrossRef]

(C) 2020 by the authors. Licensee MDPI, Basel, Switzerland. This article is an open access article distributed under the terms and conditions of the Creative Commons Attribution (CC BY) license (http://creativecommons.org/licenses/by/4.0/). 